\title{
Formulation of Culture Media for Conductimetric Assays: Theoretical Considerations
}

\author{
By J. D. OWENS \\ Department of Food Technology, University of Reading, Whiteknights, Reading RG6 2AP, UK
}

(Received 17 May 1985; revised 4 July 1985)

The basic theory of electrolytic conductivity in solutions is described and a model is proposed which allows the direction and relative rates of change of conductivity in microbial cultures to be predicted. Guidelines are presented to enable nutrients to be selected so as to maximize conductivity changes. It is shown that a major consideration in any strategy to maximize conductivity changes in cultures must be to direct as many metabolic activities as possible to act in concert in the production or consumption of protons, and to combine this with use of a $\mathrm{pH}$ buffer that exhibits a large change in conductivity on taking up or losing a proton. The ability to predict conductivity changes in microbial systems should permit the rational design of culture media for the selective enumeration of microbes by conductimetric methods and the development of other kinds of conductimetric assays.

\section{INTRODUCTION}

From the earliest studies of conductivity changes in microbial systems (Stewart, 1899) it has been hoped that these changes might be related to specific microbial activities, such that conductivity changes might be used to assay these activities. Uschinski (1903) attributed the increase in conductivity in his media to ammonium salts formed by the activities of the bacteria and Oker-Blom (1912) presumed that the initial increase of conductivity in milk cultures was due to conversion of lactose to lactic acid. Parsons \& Sturges (1926) obtained excellent correlations between increases in ammonia or ammonia plus amino nitrogen concentrations and increases in the conductivity of cultures of clostridia in various proteinaceous media. With further developments in the understanding of bacterial metabolism, Allison et al. (1938) could write $\therefore$. . some kind of a relationship between variables such as $\mathrm{NH}_{3}, \mathrm{CO}_{2},\left[\mathrm{H}^{+}\right]$, numbers of bacteria, specific conductivity etc. must exist.... These speculations emphasize the fact that if the mechanisms of coordination between these variables were known, then the measurement of a single variable such as specific conductivity would permit an integration of the whole process of metabolism.'

The current interest in and commercial application of conductimetric and impedimetric techniques to the assessment of microbial populations in medical, pharmaceutical and food samples dates from papers by Cady (1975), Ur \& Brown (1975) and Richards et al. (1978). Although Richards et al. (1978) gave a lucid description of the basic nature of the processes involved in conductivity changes in cultures, there has been essentially no progress towards understanding the relationships between metabolic activities and conductivity changes since the statements of Allison et al. (1938). So poor, in fact, is the theoretical knowledge that it is not always possible to anticipate whether a particular organism-medium combination will lead to an increase or a decrease in conductivity of the medium. Eden \& Eden (1984) and FirstenbergEden \& Eden (1984) described an 'electro-bacteriological' model but this embodies only the general principle that the conductivity change is proportional to the amount of growth and does not help in the design of culture media for conductimetric assays.

Consequently, the application of conductimetric and impedimetric methods to the assay of microbial populations has been almost entirely dependent on the empirical development of 
suitable culture media. Such an approach with systems as complex as microbe-culture medium interactions is expensive and yields data having limited predictive value. Methodologies whose underlying basic mechanisms are unknown may be inherently unreliable. For instance, McMurdo \& Whyard (1984) described the case of a heat-treated skim milk powder that was heavily contaminated with coryneform bacteria but which gave a constant impedimetric response irrespective of the number of coryneform bacteria present. It appeared that the coryneform bacteria were outgrown by the small number of Bacillus in the powder, and the impedimetric response recorded was thus effectively a function of the number of Bacillus present. The importance to the interpretation of biochemical conductimetric assays of understanding all the sources of conductivity changes in microbial systems has recently been emphasized by Owens et al. (1985).

It is evident that wider exploitation of conductimetric techniques in microbiology and biochemistry requires a thorough understanding of the sources of conductivity changes. Once these are known media may be rationally formulated so as to maximize conductivity changes and hence enhance their sensitivity for the enumeration of microbes. Additionally, it may become easier to design media for the enumeration and/or identification of specific microorganisms or metabolic activities. This paper describes a model that provides such a framework. The simple theory of conductivity in solutions and the factors affecting it are first described. The available simple theoretical treatments are strictly applicable only to dilute solutions containing a small number of different kinds of ions. Nevertheless, their application to microbial cultures does allow many of the factors that determine the direction and rate of conductivity changes in cultures to be identified. Such information is quite adequate for the rational formulation of culture media for conductimetric assays. Changes in impedance (the resistance to the flow of an alternating current, comprising a conductance and a capacitance component) in microbial cultures are even less well understood than conductivity changes (Firstenberg-Eden \& Eden, 1984). Since the exact mechanisms by which microbial growth might affect capacitance are unknown, impedance is not considered in this paper.

\section{BASIC THEORY OF ELECTRICAL CONDUCTIVITY IN SOLUTIONS}

The following account is largely compiled from Bockris \& Reddy (1970), Crow (1979) and Davies (1967).

When two electrodes are placed in an electrolyte-containing solution and a potential difference is applied across them a drift of ions is produced in which ions move towards the electrode of opposite charge. The steady flow of charge (current) is maintained by ions taking electrons from or handing electrons to the electrodes. The ability of a solution to conduct current is evaluated from measurement of the resistance of the solution. The current flowing through a conductor under the influence of a constant e.m.f. is inversely proportional to its resistance, $R$ (expressed in ohms, $\Omega$ ). Hence, $1 / R$ is a measure of the conducting power and is called the conductance, $G$, of the solution (expressed in reciprocal ohms or siemens, S).

The resistance of any conductor is given by:

$$
R=\rho(l / A)
$$

where $l$ is the length of the conductor $(\mathrm{cm}), A$ is the cross-sectional area of the conductor $\left(\mathrm{cm}^{2}\right)$, and $\rho$ is the specific resistance or resistivity of the material $(\Omega \mathrm{cm})$. Resistivity is a property of the material and its reciprocal is called the conductivity, $\kappa$, of the material:

$$
\kappa=1 / \rho=(1 / R)(l / A)\left(\Omega^{-1} \mathrm{~cm}^{-1} \text { or } \mathrm{S} \mathrm{cm}^{-1}\right)
$$

Hence, the electrolytic conductivity of a solution is equal to the conductance of a portion $1 \mathrm{~cm}$ in length and $1 \mathrm{~cm}^{2}$ in cross-section.

To evaluate the conductivity of a solution, the resistance is measured of a portion of the solution between electrodes of fixed area and held at a fixed separation from each other. Because of the difficulty of accurately measuring the area and separation of electrodes, it is usual to first determine a cell constant $(l / A)$ by measuring the resistance of a solution of accurately known 
conductivity in the cell. The electrolytic conductivity of any electrolyte-containing solution is then given by its measured conductance between these electrodes multiplied by the cell constant:

$$
\kappa=(1 / R)(l / A)
$$

Since current in solutions is carried only by ions, it is evident that conductivity will vary with the concentration, $C$, of electrolyte:

$$
\kappa=\mathrm{f}(C)
$$

Hence, in order to compare the conducting power of different electrolytes it is necessary to define a parameter for a standard quantity of electrolyte. The molar conductivity, $\Lambda$, of an electrolyte may be defined as the conductivity of a solution (i.e. the conductance of a portion $1 \mathrm{~cm}^{2}$ by $\left.1 \mathrm{~cm}\right)$ divided by the concentration of electrolyte $\left(C, \mathrm{~mol} \mathrm{~cm}^{-3}\right)$ :

$$
\Lambda=\kappa / C\left(\mathrm{~S} \mathrm{~cm}^{2} \mathrm{~mol}^{-1}\right)
$$

Thus molar conductivity is a measure of the conducting power of 1 mole of electrolyte at any concentration, and the conductivity of a solution at a particular concentration, $c\left(\mathrm{~mol} \mathrm{l}^{-1}\right)$, is given by:

$$
1000 \kappa=\Lambda c\left(\mathrm{~S} \mathrm{~cm}^{-1}\right)
$$

where the 1000 multiplier converts concentrations to mol $^{-1}$. Molar conductivity is defined as above, rather than as the conductivity at a fixed concentration, because it is not a constant parameter but varies with concentration. As a solution of an electrolyte is made more dilute the molar conductivity increases and approaches a limiting value called the molar conductivity at infinite dilution, $\Lambda_{0}$. This change is attributed to the lessening of interionic interactions as the ions become further apart with dilution.

Quantitative relationships between molar conductivity and electrolyte concentration

For strong electrolytes Kohlraush established the empirical relationship:

$$
\Lambda=\Lambda_{0}-K c^{1 / 2}
$$

where $K$ is a constant mainly controlled by the valency of the ions. For uni-univalent salts (e.g. $\mathrm{KCl}, \mathrm{NaCl}$ ) this equation holds up to concentrations of about $0.005 \mathrm{~mol} \mathrm{l}^{-1}$. Extrapolation of the plot of $\Lambda$ against $c^{1 / 2}$ allows determination of $\Lambda_{0}$. Onsager used the interionic attraction theory of Debye and Hückel to provide a theoretical basis for the Kohlraush relationship:

$$
\Lambda=\Lambda_{0}-\left(a \Lambda_{0}+b\right) c^{1 / 2}
$$

where $a$ and $b$ are constants depending upon the valencies of the two ions, the dielectric constant of the solvent, its viscosity, and the absolute temperature. For uni-univalent salts in water at $25^{\circ} \mathrm{C}, a=0.2292$ and $b=60 \cdot 22$.

The Onsager equation is quite successful at predicting the initial fall in conductivity with increase in concentration for simple solutions of uni-univalent salts up to concentrations of about $0.001 \mathrm{~mol} \mathrm{l}^{-1}$ and of some uni-divalent salts up to rather lower concentrations, but no case is known in which a salt with a valency product of 4 or more obeys the equation at accessible concentrations. This is believed to be due to the occurrence in these solutions of ion-pairs held together by the strong electrostatic forces to which multivalent ions are subject. As a result of these forces, a pair of oppositely charged ions coming into close contact remain for a time under each other's influence and lose their independent identities. Thus a solution of $\mathrm{Na}_{2} \mathrm{SO}_{4}$ is envisaged as including the species $\mathrm{NaSO}_{4}^{-}$as well as $\mathrm{Na}^{+}$and $\mathrm{SO}_{4}^{2-}$ and its conductivity is therefore lower than predicted by the Onsager equation. For example, whereas the molar conductivity of $0.01 \mathrm{M}-\mathrm{KCl}$ is approximately $94 \%$ of the value at infinite dilution, that of $0.01 \mathrm{M}$ $\mathrm{Na}_{2} \mathrm{SO}_{4}$ is $87 \%$ and that of $0.01 \mathrm{M}-\mathrm{CuSO}_{4}$ is $62 \%$. At concentrations of $0.1 \mathrm{M}$ the figures are 86 , 69 and $38 \%$ of the respective molar conductivities at infinite dilution (Conway, 1952). 
Equations have been developed that take account of ion-pair formation but they also are only successful at concentrations substantially lower than those relevant to microbiological culture media (e.g. Pethybridge, 1982) and their further consideration here is not justified.

\section{Effect of total ionic strength on conductivity}

All the ions in a solution will contribute to the ion atmospheres and thus it is the total ionic concentration that governs the decrease in conductivity from that at infinite dilution. The ion atmosphere effects are determined by the ionic strength $I$ :

$$
I=0.5 \Sigma z_{i}^{2} c_{i}
$$

where $z$ is the numerical value of the charge of the $i$ th ion, and $c$ is its concentration $\left(\mathrm{mol} \mathrm{l}^{-1}\right)$. For example, in a solution which is $0.001 \mathrm{M}$ in $\mathrm{NaCl}$ and $0.001 \mathrm{M}$ in $\mathrm{KCl}$, the ionic strength is $0.002 \mathrm{~mol}^{-1}$ and, as a first approximation, the conductivity of the solution may be calculated using the molar conductivities at $c$ equal to $0.002 \mathrm{~mol} \mathrm{l}^{-1}$.

$$
1000 \kappa=\left(\Lambda_{\mathrm{NaCl}}^{0.002} \times 0.001\right)+\left(\Lambda_{\mathrm{KCl}}^{0.002} \times 0.001\right)
$$

where $\Lambda_{\mathrm{NaCl}}^{0.002}$ is the molar conductivity of $0.002 \mathrm{M}-\mathrm{NaCl}$, and $\Lambda_{\mathrm{KCl}}^{0.002}$ is the molar conductivity of $0.002 \mathrm{M}-\mathrm{KCl}$.

Due to the charge-squared term in the calculation of $I$, bivalent or higher valent ions have a greater effect on ionic strength than univalent ions and hence their presence in solutions results in a greater depression of the conductivity than the equivalent amount of univalent ions.

\section{Effect of temperature on conductivity}

Molar conductivity increases with increase in temperature due, primarily, to the decrease in the viscosity of the solvent with increasing temperature. For nearly all ions except $\mathrm{H}^{+}$and $\mathrm{OH}^{-}$ the rate of change is $1.018-1.022^{\circ} \mathrm{C}^{-1}$. For $\mathrm{H}^{+}$it is $1.042^{\circ} \mathrm{C}^{-1}$ and for $\mathrm{OH}^{-}$it is $1.016^{\circ} \mathrm{C}^{-1}$. Richards et al. (1978) reported a mean value of $1.016^{\circ} \mathrm{C}^{-1}$ for some common culture media. Hence, when conductivities, and especially changes in conductivities, are determined it is very important that temperature control is precise. In the absence of compensation for temperature changes, to detect changes in conductivity with a precision of 1 in $10^{5}$, temperature must vary by less than $0.0006^{\circ} \mathrm{C}$ (Richards et al., 1978).

\section{Effects of other factors on conductivity}

Two other factors that can substantially influence the conductivity of solutions are the viscosity and the dielectric constant of the solvent. However, in most liquid aqueous culture media neither of these is likely to have values greatly different from those of pure water.

\section{Conductivity of mixtures of electrolytes}

In principle the conductivity of mixtures of electrolytes may be calculated by summing the conductivities of the individual ions. For example, for a mixture of $0.001 \mathrm{M}-\mathrm{KCl}$ and $0.001 \mathrm{M}$ $\mathrm{NaCl}$ :

$$
1000 \kappa=\left(\lambda_{\mathrm{Na}} \times 0.001\right)+\left(\lambda_{\mathrm{K}} \times 0.001\right)+\left(\lambda_{\mathrm{Cl}} \times 0.002\right)
$$

where $\lambda$ is the molar conductivity of the respective ions $\left(\mathrm{S} \mathrm{cm}^{2} \mathrm{~mol}^{-1}\right)$. However, as indicated above, while it is possible to calculate the molar conductivities of ions in dilute solutions containing two or three ion types with reasonable accuracy, it is not feasible to calculate accurate values in more complex solutions even when dilute, let alone at the concentrations existing in culture media.

In solutions of complex mixtures of uni- and higher valent ions, ion-pair formation is likely to be very significant. For example, in seawater it is estimated (Butler, 1982) that sulphate is present as (approximate \% of total): $\mathrm{SO}_{4}^{2-}, 50 ; \mathrm{MgSO}_{4}$ ion-pairs, $25 ; \mathrm{NaSO}_{4}^{-}, 20 ; \mathrm{CaSO}_{4}, 4$; $\mathrm{KSO}_{4}^{-}, 1$; carbonate is present as $\mathrm{CO}_{3}^{2-}, 10 ; \mathrm{MgCO}_{3}, 67 ; \mathrm{CaCO}_{3}, 7 ; \mathrm{NaCO}_{3}^{-}, 17$; and bicarbonate is present as $\mathrm{HCO}_{3}^{-}, 71 ; \mathrm{MgHCO}_{3}^{+}, 17 ; \mathrm{NaHCO}_{3}, 8 ; \mathrm{CaHCO}_{3}^{+}, 3$. The percentages of metal ions present as free cations are estimated to be: $\mathrm{Na}^{+}, 99 ; \mathrm{K}^{+}, 98 ; \mathrm{Mg}^{2+}, 86$ and $\mathrm{Ca}^{2+}, 88$ 


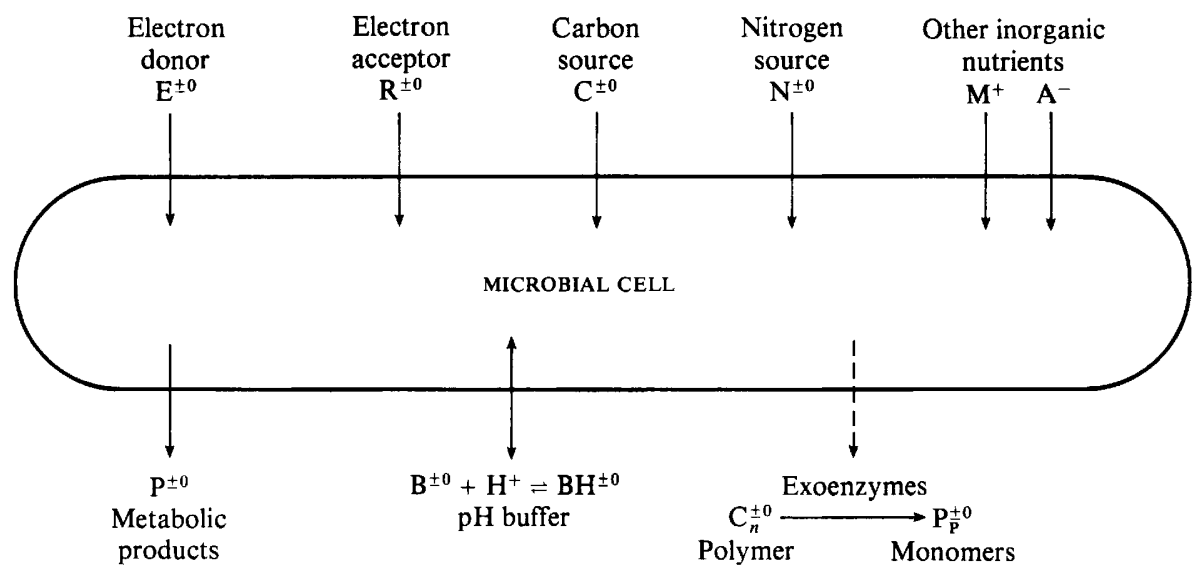

Fig. 1. Diagrammatic representation of a microbial cell and its interactions with the external environment. $E^{ \pm 0}, R^{ \pm 0}$, etc. represent compounds with net positive, negative or zero charge.

(i.e. the major anion is $\mathrm{Cl}^{-}$which is not involved in ion-pairing). Thus ion-pairing obviously removes many ions from current carrying and will have a large effect on the conductivity of the mixture. It also results in a lowering of the total ionic strength, from 0.71 to $0.66 \mathrm{~mol} \mathrm{~kg}^{-1}$ in the case of seawater, and acid-base equilibria are affected by the removal of ions, such as $\mathrm{HCO}_{3}^{-}$ and $\mathrm{CO}_{3}^{2-}$, from their acid-base equilibria.

\section{CONDUCTIVITY CHANGES IN MICROBIAL CULTURES}

Microbial culture media contain a great diversity of ionic species and it can be anticipated that substantial ion-pairing and other kinds of interionic interactions will occur, such that the calculation of absolute conductivities of culture media is not feasible. However, since we are concerned only with identifying the sources of the conductivity changes that occur in cultures as a result of the metabolic activities of micro-organisms, it is not essential that conductivity calculations yield accurate values for them to be useful. Rather, for the purpose of the rational formulation of culture media for conductimetric assays, it will suffice if they allow the relative rates of change and their directions to be predicted for different medium-micro-organism combinations.

A micro-organism may be represented as a compartment engaged in exchanging compounds with the external environment. These compounds may be classed as electron donors, final electron acceptors, carbon sources, nitrogen sources, other inorganic nutrients and metabolic products, all of which may be charged or uncharged (Fig. 1). Although microbial cells often carry a net negative charge it will be assumed here that cells are electrically neutral and not involved in carrying current. Even though this is not strictly true, the conductivity of microbial cells is negligible compared with the changes in conductivity of small ions associated with growth (Richards et al., 1978). It is also assumed that any net charge accumulated by microbial cells is negligible compared with the overall charge flux. Hence, the uptake of charged ions must be balanced by uptake of oppositely charged ions or excretion of similarly charged ones. In aqueous culture media any net uptake or excretion of charge can be presumed to be balanced by uptake or excretion of $\mathrm{H}^{+}$or $\mathrm{OH}^{-}$ions (Roos \& Luckner, 1984). If these react with $\mathrm{pH}$ buffer compounds in the medium then this is liable to lead to changes in the conductivities of the buffers. One other possible source of conductivity changes in cultures shown in Fig. 1 is the hydrolysis of polymers by excreted exoenzymes. 


\section{Calculation of conductivity changes in cultures}

In principle, the conductivity change in a culture medium as a consequence of microbial growth can be calculated by summing the net effects of all the processes illustrated in Fig. 1. To do this requires that a number of assumptions be made.

(i) Removal of ions from current carrying due to ion-pair formation or chelation is neglected.

(ii) Current carried by microbial cells or charged polymers such as proteins is neglected.

(iii) Any net accumulation of charge by microbial cells is neglected.

(iv) There is only one compound that functions as a $\mathrm{pH}$ buffer at the $\mathrm{pH}$ of the culture. If the culture produces $\mathrm{CO}_{2}$ then buffering due to $\mathrm{CO}_{2} / \mathrm{HCO}_{3}^{-}$may also need to be taken into account. None of the other electron donors, electron acceptors, carbon sources, nitrogen sources or metabolic products function as $\mathrm{pH}$ buffers in the $\mathrm{pH}$ range of the culture.

(v) Conductivity due to $\mathrm{H}^{+}$and $\mathrm{OH}^{-}$is neglected. In the $\mathrm{pH}$ range of about 3-10 the concentrations of these ions are so low compared with those of other ionic species that this assumption is justified.

(vi) The effects of ionic strength, and changes in ionic strength, on $\mathrm{p} K_{\mathrm{a}}$ values are neglected (if desired, these effects could be allowed for relatively easily).

(vii) The amount of any exoenzymes excreted is proportional to the amount of growth and, once synthesized, exoenzymes are not degraded.

(viii) The viscosity of the culture medium does not change sufficiently during growth to have a significant effect on the molar conductivities of the ions present.

\section{Total conductivity of culture medium}

Accepting the above assumptions, the conductivity of a culture medium at any instant is then given by the sum of the product of the concentration of each ionic species and its molar conductivity:

$$
\begin{aligned}
& 1000 \kappa_{\mathrm{T}}=\left[\mathrm{E}^{ \pm}\right] \lambda_{\mathrm{E}}+\left[\mathrm{R}^{ \pm}\right] \lambda_{\mathrm{R}}+\left[\mathrm{C}^{ \pm}\right] \lambda_{\mathrm{C}}+\left[\mathrm{N}^{ \pm}\right] \lambda_{\mathrm{N}}+ \\
& {\left[\mathrm{M}^{+}\right] \lambda_{\mathrm{M}}+\left[\mathrm{A}^{-}\right] \lambda_{\mathrm{A}}+\left[\mathrm{P}^{ \pm}\right] \lambda_{\mathrm{P}}+\left[\mathrm{B}^{ \pm}\right] \lambda_{\mathrm{B}}+\left[\mathrm{BH}^{ \pm}\right] \lambda_{\mathrm{BH}}+\left[\mathbf{P}_{\mathbf{P}}^{ \pm}\right] \lambda_{\mathbf{P}_{\mathrm{P}}}}
\end{aligned}
$$

where $\kappa_{\mathrm{T}}$ is the total conductivity of the culture medium $\left(\mathrm{S} \mathrm{cm}^{-1}\right),\left[\mathrm{E}^{ \pm}\right],\left[\mathrm{R}^{ \pm}\right]$, etc., are the concentrations of ions bearing one or more net positive or negative charges $\left(\mathrm{mol} \mathrm{l}^{-1}\right)$ and letters within the brackets have the same meanings as in Fig. 1, and $\lambda$ is the molar conductivity (S $\mathrm{cm}^{2} \mathrm{~mol}^{-1}$ ) of the ion indicated by the subscript.

\section{Change in conductivity with growth}

The change in conductivity of the medium for a given amount of growth is given by:

$$
\Delta \kappa_{\mathrm{T}}=\Delta \kappa_{\mathrm{E}}+\Delta \kappa_{\mathrm{R}}+\Delta \kappa_{\mathrm{C}}+\Delta \kappa_{\mathrm{N}}+\Delta \kappa_{\mathrm{MA}}+\Delta \kappa_{\mathrm{P}}+\Delta \kappa_{\mathrm{B} / \mathrm{BH}}+\Delta \kappa_{\mathrm{P}_{\mathrm{P}}}
$$

where $\Delta \kappa_{\mathrm{E}}, \Delta \kappa_{\mathrm{R}}$, etc., are the changes in the conductivity of the component of the medium indicated by the subscript.

Change in conductivity due to electron donor, electron acceptor, carbon source, nitrogen source and other inorganic nutrients. These are given by the following relationships, where subscript 1 indicates a final state after growth has occurred:

$$
\begin{array}{rlrl}
1000 \Delta \kappa_{\mathrm{E}} & =-\left(X_{1} / Y_{\mathrm{E}}\right) \lambda_{\mathrm{E}} & 1000 \Delta \kappa_{\mathrm{R}}=-\left(X_{1} / Y_{\mathrm{R}}\right) \lambda_{\mathrm{R}} \\
1000 \Delta \kappa_{\mathrm{C}} & =-\left(X_{1} / Y_{\mathrm{C}}\right) \lambda_{\mathrm{C}} & & 1000 \Delta \kappa_{\mathrm{N}}=-\left(X_{1} / Y_{\mathrm{N}}\right) \lambda_{\mathrm{N}} \\
1000 \Delta \kappa_{\mathrm{MA}} & =-\Sigma\left(X_{1} / Y_{\mathrm{MA}}\right) \lambda_{\mathrm{MA}} & &
\end{array}
$$

where $X_{1}$ is the concentration of biomass formed ( $\mathrm{g}$ dry biomass $\mathrm{1}^{-1}$ ), $Y$ is the yield coefficient for the nutrient indicated by the subscript ( $\mathrm{g}$ dry biomass $\mathrm{mol}^{-1}$ ), and MA refers to any inorganic cation or anion.

Change in conductivity due to excreted products other than $\mathrm{CO}_{2}, 1000 \Delta \kappa_{\mathrm{P}}=\Sigma\left(n X_{1} / Y\right) \lambda_{\mathrm{P}}$, where $Y$ is the yield coefficient with respect to the nutrient precursor of the product (i.e. $Y_{\mathrm{E}}, Y_{\mathrm{R}}, Y_{\mathrm{C}}$ or $Y_{\mathrm{N}}, \mathrm{g}$ dry biomass $\mathrm{mol}^{-1}$ ), and $n$ is the number of moles of product formed per mole of precursor nutrient consumed. 
Change in conductivity due to the $p H$ buffer. The net concentration of $\mathrm{H}^{+}$leaving the cell for a given concentration of biomass produced is given by:

$$
\mathrm{H}_{\text {out }}^{+}=\Sigma z_{\mathrm{i}} \Delta\left[\mathrm{I}^{+}\right]_{\text {in }}-\Sigma z_{\mathrm{i}} \Delta\left[\mathrm{I}^{-}\right]_{\text {in }}+\Sigma z_{\mathrm{i}} \Delta\left[\mathrm{P}^{-}\right]_{\text {out }}-\Sigma z_{\mathrm{i}} \Delta\left[\mathrm{P}^{+}\right]_{\text {out }}
$$

where $\mathrm{H}_{\text {out }}^{+}$is the net concentration of $\mathrm{H}^{+}$excreted $\left(\mathrm{moll}^{-1}\right), \Delta\left[\mathrm{I}^{+}\right]_{\text {in }}$ is the change in concentration of any ion bearing positive charge, $z_{\mathrm{i}}$, taken up by cells (i.e. $\mathrm{E}^{+}, \mathrm{R}^{+}, \mathrm{C}^{+}, \mathrm{N}^{+}, \mathrm{M}^{+}$, mol $\left.\mathrm{l}^{-1}\right), \Delta\left[\mathrm{I}^{-}\right]_{\mathrm{in}}$ is the change in concentration of any ion bearing negative charge, $z_{\mathrm{i}}$, taken up by cells (i.e. $\left.\mathrm{E}^{-}, \mathrm{R}^{-}, \mathrm{C}^{-}, \mathrm{N}^{-}, \mathrm{A}^{-}, \mathrm{mol} \mathrm{l}^{-1}\right), \Delta\left[\mathrm{P}^{-}\right]_{\text {out }}$ is the change in concentration of any ion bearing negative charge, $z_{\mathrm{i}}$, excreted by cells $\left(\mathrm{mol} \mathrm{l}^{-1}\right)$, and $\Delta\left[\mathrm{P}^{+}\right]_{\text {out }}$ is the change in concentration of any ion bearing positive charge, $z_{\mathrm{i}}$, excreted by cells $\left(\mathrm{mol}^{-1}\right)$.

In the buffering zone of the $\mathrm{pH}$ buffer (i.e. $\mathrm{pH} \sim \mathrm{p} K_{\mathrm{a}} \pm 1$ ) the $\mathrm{H}_{\text {out }}^{+}$will be entirely absorbed by the buffer (since any change in $\left[\mathrm{H}^{+}\right]$is negligible compared with $\mathrm{H}_{\text {out }}^{+}$):

$$
\mathrm{B}^{ \pm \mathbf{0}}+\mathrm{H}_{\text {out }}^{+} \rightarrow \mathrm{BH}^{ \pm 0}
$$

where $\mathrm{B}^{ \pm 0}$ represents the conjugate base bearing net positive, negative or zero charge, and $\mathrm{BH}^{ \pm 0}$ represents the conjugate acid bearing net positive, negative or zero charge. Thus:

$$
1000 \Delta \kappa_{\mathrm{B} / \mathrm{BH}}=\left(\mathrm{H}_{\text {out }}^{+}\right)\left(\lambda_{\mathrm{BH}}-\lambda_{\mathrm{B}}\right)
$$

where $\lambda_{\mathrm{BH}}$ is the molar conductivity of conjugate acid and $\lambda_{\mathrm{B}}$ is the molar conductivity of conjugate base.

Correction to calculations for $\mathrm{pH}$ buffer and excreted products to take account of $\mathrm{CO}_{2}$ production. Since $\mathrm{CO}_{2}$ is such a frequent product of microbial metabolism, and has a p $K_{\mathrm{a} 1}$ of 6.35 , it is necessary (if the $\mathrm{CO}_{2}$ is retained in the culture) to correct the calculations for $\mathrm{H}_{\text {out }}^{+}$and those for changes in conductivity to take account of the proportion of $\mathrm{CO}_{2}$ present as $\mathrm{HCO}_{3}^{-}$. The effect of the hydrolysis of $\mathrm{CO}_{2}$ to bicarbonate is the formation of an additional $\mathrm{H}^{+}$and the conversion of an additional molecule of buffer conjugate base to conjugate acid:

Adding:

$$
\begin{gathered}
\mathrm{CO}_{2}+\mathrm{H}_{2} \mathrm{O} \rightarrow \mathrm{HCO}_{3}^{-}+\mathrm{H}^{+} \\
\mathrm{B}^{ \pm 0}+\mathrm{H}^{+} \rightarrow \mathrm{BH}^{ \pm 0}
\end{gathered}
$$

$$
\mathrm{CO}_{2}+\mathrm{H}_{2} \mathrm{O}+\mathrm{B}^{ \pm 0} \rightarrow \mathrm{HCO}_{3}^{-}+\mathrm{BH}^{ \pm 0}
$$

The extent to which this reaction occurs depends upon the $\mathrm{p} K_{\mathrm{a}}$ of the particular buffer, and may be calculated as follows.

Since

$$
\left[\mathrm{H}^{+}\right]_{1}=\frac{K_{1}^{\mathrm{C}}\left(C_{\mathrm{T}}^{\mathrm{C}}-\left[\mathrm{HCO}_{3}^{-}\right]_{1}\right)}{\left[\mathrm{HCO}_{3}^{-}\right]_{1}}
$$

and

$$
\begin{aligned}
{\left[\mathrm{H}^{+}\right]_{1} } & =\frac{K^{\mathrm{B}}[\mathrm{HB}]_{1}}{[\mathrm{~B}]_{1}} \\
& =\frac{K^{\mathrm{B}}\left([\mathrm{HB}]_{\mathrm{t}}+\left[\mathrm{HCO}_{3}^{-}\right]_{1}\right)}{[\mathrm{B}]_{\mathrm{t}}-\left[\mathrm{HCO}_{3}^{-}\right]_{1}}
\end{aligned}
$$

where $K_{1}^{\mathrm{C}}$ is the first dissociation constant for carbonic acid, $C_{\mathrm{T}}^{\mathrm{C}}$ is the total concentration of $\mathrm{CO}_{2}$ produced $\left(\mathrm{mol} \mathrm{l}^{-1}\right),\left[\mathrm{HCO}_{3}^{-}\right]_{1}$ is the final concentration of $\mathrm{HCO}_{3}^{-}\left(\mathrm{mol} \mathrm{l}^{-1}\right), K^{\mathrm{B}}$ is the dissociation constant for the $\mathrm{pH}$ buffer, $[\mathrm{B}]_{1}$ is the final concentration of the conjugate base of the buffer $\left(\mathrm{mol} \mathrm{l}^{-1}\right),[\mathrm{BH}]_{1}$ is the final concentration of the conjugate acid of the buffer $\left(\mathrm{mol} \mathrm{l}^{-1}\right),[\mathrm{B}]_{\mathrm{t}}$ is the 'transition' concentration of $\mathrm{B}$ calculated without taking $\mathrm{HCO}_{3}^{-}$formation into account, and $[\mathrm{BH}]_{\mathrm{t}}$ is the 'transition' concentration of $\mathrm{HB}$ calculated without taking $\mathrm{HCO}_{3}^{-}$formation into account. Thus:

$$
\frac{K_{1}^{\mathrm{C}}\left(C_{\mathrm{T}}^{\mathrm{C}}-\left[\mathrm{HCO}_{3}^{-}\right]_{1}\right)}{\left[\mathrm{HCO}_{3}^{-}\right]_{1}}=\frac{K^{\mathrm{B}}\left([\mathrm{BH}]_{\mathrm{t}}+\left[\mathrm{HCO}_{3}^{-}\right]_{1}\right)}{[\mathrm{B}]_{\mathrm{t}}-\left[\mathrm{HCO}_{3}^{-}\right]_{1}}
$$


Rearranging:

$$
\left(K_{1}^{\mathrm{C}}-K^{\mathrm{B}}\right)\left(\left[\mathrm{HCO}_{3}^{-}\right]_{1}\right)^{2}-\left(K_{1}^{\mathrm{C}}[\mathrm{B}]_{\mathrm{t}}+K_{1}^{\mathrm{C}} C_{\mathrm{T}}^{\mathrm{C}}+K^{\mathrm{B}}[\mathrm{BH}]_{\mathrm{t}}\right)\left[\mathrm{HCO}_{3}^{-}\right]_{1}+K_{1}^{\mathrm{C}} C_{\mathrm{T}}^{\mathrm{C}}[\mathrm{B}]_{\mathrm{t}}=0
$$

Thus $\left[\mathrm{HCO}_{3}^{-}\right]_{1}$ can be calculated by solving this quadratic equation and the final $\mathrm{pH}$ determined from:

$$
\left[\mathrm{H}^{+}\right]_{1}=\frac{K^{\mathrm{B}}\left([\mathrm{HB}]_{\mathrm{t}}+\left[\mathrm{HCO}_{3}^{-}\right]_{1}\right)}{[\mathrm{B}]_{\mathrm{t}}-\left[\mathrm{HCO}_{3}^{-}\right]_{1}}
$$

The concentrations of $\mathrm{B}$ and $\mathrm{BH}$ can then be determined, since:

thus

$$
\begin{gathered}
K^{\mathrm{B}}=\frac{[\mathrm{B}]_{1}\left[\mathrm{H}^{+}\right]_{1}}{[\mathrm{BH}]_{1}}=\frac{[\mathrm{B}]_{1}\left[\mathrm{H}^{+}\right]_{1}}{C_{\mathrm{T}}^{\mathrm{B}}-[\mathrm{B}]_{1}} \\
{[\mathrm{~B}]_{1}=\frac{C_{\mathrm{T}}^{\mathrm{B}} K^{\mathrm{B}}}{\left[\mathrm{H}^{+}\right]_{1}+K^{\mathrm{B}}}}
\end{gathered}
$$

and

$$
[\mathrm{BH}]_{1}=C_{\mathrm{T}}^{\mathrm{B}}-[\mathrm{B}]_{1}
$$

where $C_{\mathrm{T}}^{\mathrm{B}}$ is the total concentration of buffer present.

Change in conductivity due to hydrolysis of polymers external to the cells. Since it is assumed that the concentration of exoenzyme produced is proportional to the amount of growth, the amount of hydrolysis of external polymers in a culture growing at a constant rate under constant conditions will also be proportional to the concentration of biomass formed:

$$
\left[\mathrm{P}_{\mathrm{P}}^{ \pm}\right]_{1}=X_{1} Y_{\mathrm{P}_{\mathrm{P}}}
$$

where $X_{1}$ is the concentration of biomass formed (gdry biomass $\mathrm{l}^{-1}$ ) and $Y_{\mathrm{P}_{\mathrm{P}}}$ is the yield coefficient for polymer hydrolysis [mol products ( $\left(\mathrm{g}\right.$ biomass) $\left.{ }^{-1}\right]$. Thus:

$$
1000 \Delta \kappa_{\mathrm{P}_{\mathrm{p}}}=X_{1} Y_{\mathrm{P}_{\mathrm{p}}} \lambda_{\mathrm{P}_{\mathrm{p}}}
$$

where $\Delta \kappa_{\mathrm{P}_{\mathrm{p}}}$ is the change in conductivity due to polymer hydrolysis, and $\lambda_{\mathrm{P}_{\mathrm{p}}}$ is the molar conductivity of the product of the hydrolysis.

Total change in conductivity of culture media due to microbial growth. Using the arguments presented above, it is possible to determine the changes in the concentrations of all the ionic species present following a specified amount of microbial growth, but what are not known are the molar conductivities of the ions under the prevailing conditions. As indicated earlier, it is not possible to calculate accurately the molar conductivities of ions in complex mixtures. Hence it is necessary to assume, as a first approximation, that the molar conductivities of the different ions are reduced proportionately by similar amounts from their values at infinite dilution. (This assumption is not strictly true even for dilute solutions of $1: 1$ electrolytes since the reduction is given by $\left(a \Lambda_{0}+b\right) c^{1 / 2}$ in the Onsager equation. In mixtures of electrolytes involving significant ion-pairing, it certainly involves some degree of error. If greater precision were required the extent of ion-pair formation could be roughly estimated, but this is not justified here.) Thus, for the purposes of comparing the relative contributions of the changes in the conductivity of each of the medium components to the total change in conductivity of the medium, molar conductivities at infinite dilution may be used. The molar conductivities at infinite dilution of some ions relevant to microbial cultures are listed in Table 1.

In Table 2 the calculated relative contributions of different medium components are shown for a hypothetical organism growing on glucose by a homolactic fermentation. It is apparent that the overall change in conductivity is a consequence of decreases in some components of the medium and increases in others. It follows that the overall change in medium conductivity could be maximized by ensuring that the changes in the conductivity of the components exhibiting the larger changes are all in the same direction. 
Table 1. Molar conductivities at infinite dilution of ions in aqueous solution at $25^{\circ} \mathrm{C}$

The values are taken from: $a$, Stark \& Wallace (1982); $b$, Erdey-Gruz (1974); $c$, Parsons (1959); $d$, Pethybridge \& Taba (1982); e, Pethybridge et al. (1983).

\begin{tabular}{|c|c|c|c|}
\hline Cation & $\left(\mathrm{S} \mathrm{cm}^{\lambda_{+}^{0}} \mathrm{~mol}^{-1}\right)$ & Anion & $\left(\begin{array}{c}\lambda_{-}^{0} \\
\left(\mathrm{~S} \mathrm{~cm}^{2} \mathrm{~mol}^{-1}\right)\end{array}\right.$ \\
\hline $\mathrm{H}^{+}$ & $349 \cdot 8^{a}$ & $\mathrm{OH}^{-}$ & $198 \cdot 6^{a}$ \\
\hline$c^{+}$ & $73 \cdot 5^{a}$ & $\mathrm{Cl}^{-}$ & $76 \cdot 4^{a}$ \\
\hline $\mathrm{a}^{+}$ & $50 \cdot 1^{a}$ & $\mathrm{NO}_{3}^{-}$ & $71 \cdot 4^{a}$ \\
\hline $\mathrm{NH}_{ \pm}^{+}$ & $73 \cdot 5^{a}$ & $\mathrm{~S}_{4} \mathrm{O}_{6}^{2-}-$ & $152 \cdot 0^{d}$ \\
\hline $\mathrm{Mg}^{2+}$ & $106 \cdot 1^{d}$ & $\mathrm{~S}_{2} \mathrm{O}_{3}^{2-}$ & $174 \cdot 4^{d}$ \\
\hline $\mathrm{Ca}^{2+}$ & $118 \cdot 0^{d}$ & $\mathrm{SO}_{4}^{2-}$ & $159 \cdot 6^{d}$ \\
\hline $\mathrm{Fe}^{3+}$ & $205 \cdot 2^{a}$ & $\mathrm{H}_{2} \mathrm{PO}_{4}^{-}$ & $36^{b}$ \\
\hline $\mathrm{HOC}_{2} \mathrm{H}_{4} \mathrm{NH}_{3}^{+}$ & $42 \cdot 2^{c}$ & $\mathrm{HPO}_{4}^{2-}$ & $114^{b}$ \\
\hline $\mathrm{C}_{3} \mathrm{H}_{7} \mathrm{NH}_{3}^{+}$ & $41^{c}$ & $\mathrm{PO}_{4}^{3-}$ & $240^{a}$ \\
\hline $\left.\mathrm{C}_{3} \mathrm{H}_{7}\right)_{2} \mathrm{NH}_{2}^{ \pm}$ & $29^{c}$ & $\mathrm{HCO}_{3}^{-}$ & $44 \cdot 5^{a}$ \\
\hline $\left.\mathrm{CH}_{3}\right)_{3} \mathrm{NH}^{+}$ & $42^{c}$ & $\mathrm{CO}_{3}^{2-}$ & $118 \cdot 6^{a}$ \\
\hline $\left.\mathrm{C}_{2} \mathrm{H}_{5}\right)_{3} \mathrm{NH}^{+}$ & $34^{c}$ & $\mathrm{HCOO}^{-}$ & $54 \cdot 6^{a}$ \\
\hline $\left.\mathrm{CH}_{3}\right)_{4} \mathrm{~N}^{+}$ & $44 \cdot 9^{c}$ & $\mathrm{CH}_{3} \mathrm{COO}^{-}$ & $40 \cdot 9^{a}$ \\
\hline $\left.\mathrm{C}_{2} \mathrm{H}_{5}\right)_{4} \mathrm{~N}^{+}$ & $32 \cdot 7^{c}$ & $\mathrm{HOOCCOO}^{-}$ & $40 \cdot 2^{c}$ \\
\hline $\left.\mathrm{C}_{3} \mathrm{H}_{7}\right)_{4} \mathrm{~N}^{+}$ & $23 \cdot 5^{c}$ & $\mathrm{C}_{2} \mathrm{H}_{5} \mathrm{COO}^{-}$ & $35 \cdot 8^{c}$ \\
\hline & & $\mathrm{C}_{3}^{-} \mathrm{H}_{7} \mathrm{COO}^{-}$ & $35 \cdot 1^{\mathrm{c}}$ \\
\hline & & $\mathrm{C}_{4} \mathrm{H}_{9} \mathrm{COO}^{-}$ & $33 \cdot 4^{c}$ \\
\hline & & $\mathrm{CH}_{3} \mathrm{CHCHCHCHCOO}^{-}$ & $31 \cdot 3^{e}$ \\
\hline & & $\left(\mathrm{COO}^{-}\right)_{2}$ & $148 \cdot 4^{a}$ \\
\hline & & $\operatorname{tr}-\left(\mathrm{CHCOO}^{-}\right)_{2}$ & $123 \cdot 6^{c}$ \\
\hline & & $\left(\mathrm{CH}_{2} \mathrm{COO}^{-}\right)_{2}^{-}$ & $114 \cdot 6^{c}$ \\
\hline & & $\left(\mathrm{CH}_{2}^{-}\right)_{3}\left(\mathrm{COO}^{-}\right)_{2}$ & $105 \cdot 2^{c}$ \\
\hline & & $\left(\mathrm{CHOHCOO}^{-}\right)_{2}$ & $119 \cdot 2^{c}$ \\
\hline & & $\mathrm{CH}_{2} \mathrm{CHOH}\left(\mathrm{COO}^{-}\right)_{2}$ & $117 \cdot 6^{c}$ \\
\hline & & $\mathrm{C}_{6} \mathrm{H}_{5} \mathrm{COO}^{-}$ & $32 \cdot 3^{\mathrm{c}}$ \\
\hline & & $o-\mathrm{C}_{6} \mathrm{H}_{4}\left(\mathrm{COO}^{-}\right)_{2}$ & $104 \cdot 6^{c}$ \\
\hline
\end{tabular}

Table 2. Calculation of conductivity changes due to growth of a hypothetical bacterium on glucose by homolactic fermentation in the presence of phosphate buffer

\begin{tabular}{|c|c|c|}
\hline $\begin{array}{l}\text { Metabolic } \\
\text { activity }\end{array}$ & $\begin{array}{l}\text { Metabolite } \\
\text { flux* } \\
{[\text { mmol (g dry }} \\
\left.\text { biomass) }{ }^{-1}\right]\end{array}$ & $\begin{array}{c}\mathrm{H}^{+} \text {flux } \\
{\left[\left(\mathrm{mmol} \mathrm{\textrm {H } ^ { + } \text { out } )}\right.\right.} \\
\left.(\mathrm{g} \text { dry biomass })^{-1}\right]\end{array}$ \\
\hline
\end{tabular}

Electron donor

(glucose)

Carbon source

(glucose)

Nitrogen $\left(\mathrm{NH}_{+}^{+}\right)$

Other nutrients: $\mathrm{K}^{+}$

$\mathrm{Mg}^{2+}$

$\mathrm{Ca}^{2+}$

$\mathrm{H}_{2} \mathrm{PO}_{4}^{-} / \mathrm{HPO}_{4}^{2-}$

$\mathrm{SO}_{1-2}^{-2}$

Product

(lactate)

Buffer

$\left(\mathrm{HPO}_{4}^{2-} \rightarrow \mathrm{H}_{2} \mathrm{PO}_{4}^{-}\right)$

Totals
33

\section{7}

$$
8
$$

0.43

$0 \cdot 10$

0.008

$0 \cdot 83$

66

$73 \cdot 20$

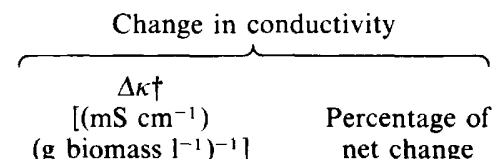

(g biomass $\left.1^{-1}\right)^{-1}$ ]

0

0

$0 \quad 0$

$-0.59+15$

$-0 \cdot 12$

$+3$

$-1 \cdot 45 \ddagger$

$+66$

$+2 \cdot 38 \S$

$-59$

$-5.71$

$+141$

$+73 \cdot 20$

$-4 \cdot 04$

100

* Yield coefficients based on Pirt (1975).

$\uparrow$ Calculated using molar conductivities at infinite dilution.

$\ddagger$ Assuming that equal amounts of $\mathrm{H}_{2} \mathrm{PO}_{4}^{-}$and $\mathrm{HPO}_{4}^{2-}$ are assimilated.

$\S$ Calculated using an estimated molar conductivity at infinite dilution for lactate of $36 \mathrm{~S} \mathrm{~cm}^{2} \mathrm{~mol}^{-1}$. 
Table 3. Calculated relative conductivity changes in microbial cultures in different culture media to illustrate the effect of carbon and energy source, nitrogen source, and electron acceptor

The values were calculated using the following assumptions: yield coefficients based on Pirt (1975); carbon content of cell $=0.5 \mathrm{~g}$ ( $\mathrm{g}$ dry biomass) ${ }^{-1} ; \mathrm{pH}$ changes occur within the buffering range of the phosphate buffer; conductivity changes calculated using molar conductivities at infinite dilution without correction for ionic strength; the energy-yielding metabolism shown applies to that portion of the carbon and energy source not assimilated.

Energy-yielding metabolism

$\mathrm{C}_{6} \mathrm{H}_{12} \mathrm{O}_{6}+6 \mathrm{O}_{2} \rightarrow 6 \mathrm{CO}_{2}+6 \mathrm{H}_{2} \mathrm{O}$

$\mathrm{C}_{6} \mathrm{H}_{12} \mathrm{O}_{6}+\mathrm{H}_{2} \mathrm{O} \rightarrow$ lactate +0.5 acetate

+0.5 ethanol $+0.5 \mathrm{HCO}_{3}^{-}$

$+0.5 \mathrm{CO}_{2}+\mathrm{H}_{2}+2 \mathrm{H}^{+}$

$\mathrm{C}_{6} \mathrm{H}_{12} \mathrm{O}_{6}+\left(\mathrm{CH}_{3}\right)_{3} \mathrm{NO}+0 \cdot 5 \mathrm{H}_{2} \mathrm{O} \rightarrow$ lactate

+ acetate $+\left(\mathrm{CH}_{3}\right)_{3} \mathrm{NH}^{+}+0.5 \mathrm{HCO}_{3}^{-}$

$+0.5 \mathrm{CO}_{2}+\mathrm{H}_{2}+1.5 \mathrm{H}^{+}$

$\mathrm{C}_{6} \mathrm{H}_{12} \mathrm{O}_{6}+\mathrm{S}_{4} \mathrm{O}_{6}^{2-}+1.5 \mathrm{H}_{2} \mathrm{O} \rightarrow$ lactate

+ acetate $+2 \mathrm{~S}_{2} \mathrm{O}_{3}^{2-}+0.5 \mathrm{HCO}_{3}^{-1}$

$+0.5 \mathrm{CO}_{2}+\mathrm{H}_{2}+4.5 \mathrm{H}^{+}$

$\left(\mathrm{CH}_{2} \mathrm{COO}^{-}\right)_{2}+3 \cdot 5 \mathrm{O}_{2}+2 \mathrm{H}^{+} \rightarrow 4 \mathrm{CO}_{2}+3 \mathrm{H}_{2} \mathrm{O}$ as above

$\mathrm{C}_{3} \mathrm{H}_{7} \mathrm{NH}_{3}^{+}+4 \cdot 5 \mathrm{O}_{2} \rightarrow 3 \mathrm{CO}_{2}+3 \mathrm{H}_{2} \mathrm{O}+\mathrm{NH}_{4}^{+}$

$\mathrm{CH}_{3} \mathrm{CHNH}_{3} \mathrm{COO}^{-}+3 \mathrm{O}_{2}+\mathrm{H}^{+} \rightarrow 3 \mathrm{CO}_{2}$

$+2 \mathrm{H}_{2} \mathrm{O}+\mathrm{NH}_{4}^{+}$

\section{Yield}

[(g dry biomass)

(mol C-source $\left.)^{-1}\right]$

80

27

30

30

40

40

25

30

Conductivity change $\left[\mu \mathrm{S} \mathrm{cm}{ }^{-1}(100 \mathrm{mg}\right.$ dry biomass $\left.1^{-1}\right)^{-1}$ ]

Nitrogen
source

$\mathrm{NH}_{4}^{+}$

$\mathrm{NH}_{4}^{+}$

$\mathrm{NH}_{4}^{+}$

$\mathrm{NH}_{4}^{+}$

$\mathrm{NH}_{4}^{+}$

$\mathrm{NO}_{3}^{-}$

$\mathrm{NH}_{4}^{+}$

$\mathrm{NH}_{4}^{+}$
$-130$

$-360^{*}$

$-60^{*}$

$-280^{*}$

$-25$

$+100$

$+5$

$+370$

* Estimated, taking $\lambda_{0}$ for lactate as $36 \mathrm{~S} \mathrm{~cm}^{2} \mathrm{~mol}^{-1}$.

It is also evident that, for this hypothetical culture, the medium component showing the greatest quantitative change in conductivity is the phosphate $\mathrm{pH}$ buffer. This is an inevitable consequence of the large $\mathrm{H}^{+}$flux. Thus a major consideration in any strategy to maximize conductivity changes in microbial cultures must be to direct as many metabolic processes as possible to act in concert in the production/consumption of $\mathrm{H}^{+}$, and to combine this with the use of a pH buffer compound that exhibits a large change in conductivity on taking up or losing a proton.

The calculations presented in Table 2 are relatively simple, but they become much more complicated when more reactions, and $\mathrm{CO}_{2}$ effects, are introduced. Table 3 shows the results of some calculations, made using a computer simulation program, that illustrate the effects of different medium compositions and microbial activities on the predicted conductivity changes in the cultures.

\section{APPROACHES TO THE MAXIMIZATION OF CONDUCTIVITY CHANGES IN CULTURE MEDIA}

The model presented here leads to a number of principles that can be applied to the formulation of culture media to maximize the conductivity changes that occur with microbial growth. The main factors to be considered, in approximate order of importance, are: (i) selection of $\mathrm{pH}$ buffer, (ii) $\mathrm{H}^{+}$flux, (iii) electron donor, (iv) external electron acceptor, (v) carbon source, (vi) nitrogen source, (vii) products of metabolism, (viii) other inorganic nutrients, (ix) other metabolic activities, $(x)$ general considerations. These will be considered in turn.

\section{Selection of $\mathrm{pH}$ buffer}

The $\mathrm{pH}$ buffer selected should exhibit a large change in molar conductivity $\left(\Delta \Lambda_{0}\right.$, at infinite dilution) upon gaining or losing a proton, so that it amplifies the $\mathrm{H}^{+}$flux due to metabolic activities. In addition, the direction of the change should be such as to aid other conductivity changes in the medium. 
The buffer compounds should also possess the desirable features described by Good \& Izawa (1972). In particular, compounds that are charged in both their acid and their basic forms are to be preferred over uncharged compounds since there is less risk of toxic effects. Since the buffering range is approximately $\mathrm{p} K_{\mathrm{a}} \pm 1$, in order to have buffers suitable for both bacterial and fungal cultures, it is desirable, at least, to have available compounds with the following properties:

(a) $\mathrm{p} K_{\mathrm{a}} \sim 7 \cdot 0$, conductivity decreases with uptake of protons. Dihydrogen phosphatehydrogen phosphate buffer meets this need well with a $\mathrm{p} K_{\mathrm{a}}$ of 7.2 and a $\Delta \Lambda_{0}$ of $-78 \mathrm{~S} \mathrm{~cm}^{2} \mathrm{~mol}^{-1}$ :

$$
\mathrm{HPO}_{4}^{2-}+\mathrm{H}^{+} \rightleftharpoons \mathrm{H}_{2} \mathrm{PO}_{4}^{-}
$$

The amine-sulphonic acid buffers of Good \& Izawa (1972) also fit this case. They offer a choice of $\mathrm{p} K_{\mathrm{a}}$ values from 6.15 to 8.55 but no information is available on their $\Delta \Lambda_{0}$ values; e.g. BES [ $N, N$-bis(2-hydroxyethyl)-2-aminoethanesulphonic acid]:

$$
\left(\mathrm{HOC}_{2} \mathrm{H}_{4}\right)_{2} \mathrm{NC}_{2} \mathrm{H}_{4} \mathrm{SO}_{3}^{-}+\mathrm{H}^{+} \rightleftharpoons\left(\mathrm{HOCH}_{2}\right)_{2} \stackrel{+}{\mathrm{NH}} \mathrm{HC}_{2} \mathrm{H}_{4} \mathrm{SO}_{3}^{-}
$$

(b) $\mathrm{p} K_{\mathrm{a}} \sim 7 \cdot 0$, conductivity increases with uptake of protons. The only commonly used biological $\mathrm{pH}$ buffer in this category is Tris [tris(hydroxymethyl)aminomethane]:

$$
\left(\mathrm{HOCH}_{2}\right)_{3} \mathrm{CNH}_{2}+\mathrm{H}^{+} \rightleftharpoons\left(\mathrm{HOCH}_{2}\right)_{3} \mathrm{CNH}_{3}
$$

However, its $\mathrm{p} K_{\mathrm{a}}$ is rather high at 8.3 and the uncharged conjugate base may be toxic. A compound that might be used at lower $\mathrm{pH}$ values is histidine, with a $\mathrm{p} K_{\mathrm{a}}$ of $6 \cdot 0$ :

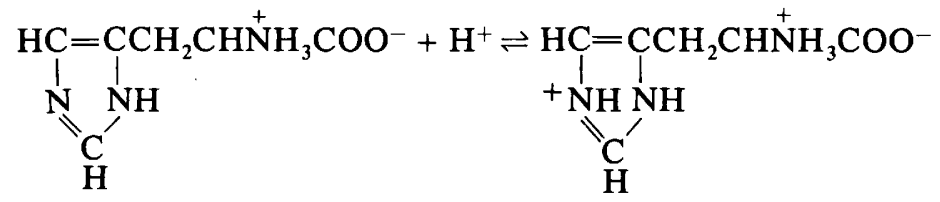

(c) $\mathrm{p} K_{\mathrm{a}} \sim 4.5$, conductivity decreases with uptake of protons. A number of common carboxylic acids have $\mathrm{p} K_{\mathrm{a}}$ values in this region, e.g. oxalate, $\mathrm{p} K_{\mathrm{a}}=4 \cdot 28$, $\Delta \Lambda_{0}=-108 \cdot 2 \mathrm{~S} \mathrm{~cm}^{2} \mathrm{~mol}^{-1}$ :

$$
{ }^{-} \mathrm{OOCCOO}^{-}+\mathrm{H}^{+} \rightleftharpoons \mathrm{HOOCCOO}^{-}
$$

citrate, $\mathrm{p} K_{\mathrm{a} 2}=4 \cdot 75, \Delta \Lambda_{0}=? ; \mathrm{p} K_{\mathrm{a} 3}=5 \cdot 45, \Delta \Lambda_{0}=$ ?:

$$
\begin{aligned}
& \mathrm{HOOCCH}_{2} \mathrm{COHCOO}^{-} \mathrm{CH}_{2} \mathrm{COO}^{-}+\mathrm{H}^{+} \rightleftharpoons \mathrm{HOOCCH}_{2} \mathrm{COHCOOHCH}_{2} \mathrm{COO}^{-} \\
&-\mathrm{OOCCH}_{2} \mathrm{COHCOO}^{-} \mathrm{CH}_{2} \mathrm{COO}^{-}+\mathrm{H}^{+} \rightleftharpoons \mathrm{HOOCCH}_{2} \mathrm{COHCOO}^{-} \mathrm{CH}_{2} \mathrm{COO}^{-}
\end{aligned}
$$

However, in some cases their possible metabolism by microbes may be a disadvantage, and citrate tends to form metal complexes which have the effect of decreasing the net charge carried and hence the conducting power.

(d) $\mathrm{p} K_{\mathrm{a}} \sim 4 \cdot 5$, conductivity increases with uptake of protons. There do not appear to be any obvious compounds to fulfil this role.

The concentration of $\mathrm{pH}$ buffer used in media should, of course, be adequate to absorb or release sufficient $\mathrm{H}^{+}$to prevent excessive $\mathrm{pH}$ drift. This might also assist in 'locking' the organisms into the desired metabolic pathway. It should also be appreciated that the $\mathrm{p} K_{\mathrm{a}}$ of acids in culture media may be different from the values given above, due to interionic interactions. If the ionic strength of the medium is known, appropriate corrections can be calculated (Butler, 1982).

$$
H^{+} \text {flux }
$$

The net $\mathrm{H}^{+}$flux into or out of the cells determines the magnitude of the buffer-mediated conductivity change. Hence, as far as possible, nutrients should be selected, and metabolism directed, to promote the maximum flux of $\mathrm{H}^{+}$in one direction. For example, in a homolactic 
Table 4. Effect of electron donor on $\mathrm{H}^{+}$flux and conductivity changes in microbial cultures

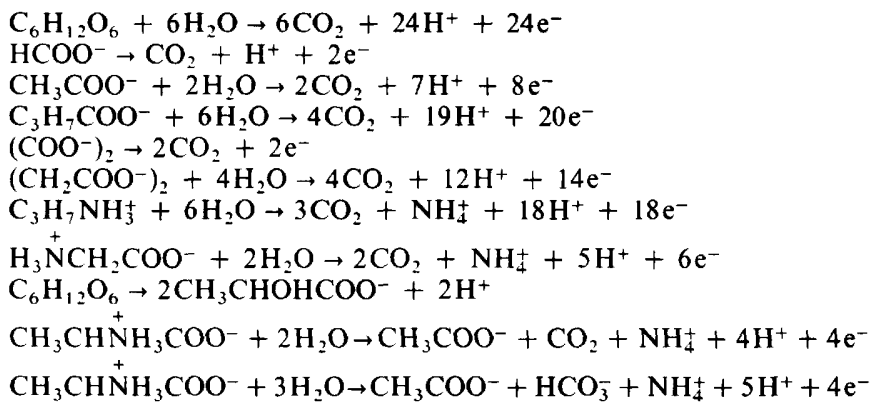

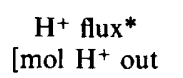

$\left.\left(2 \mathrm{e}^{-}\right)^{-1}\right]$

$\quad 0$
-1
$-0 \cdot 25$
$-0 \cdot 1$
-2
$-0 \cdot 29$
0
$-0 \cdot 33$
$+1 \ddagger$
$0 \cdot 5 \|$

Net change in conductivity [S cm² $\left.\left(2 \mathrm{e}^{-}\right)^{-1}\right]$

\footnotetext{
* All acids, other than $\mathrm{CO}_{2}$, are assumed to be fully ionized.

$\dagger$ Net change in conductivity associated with oxidation of electron donor, expressed as change at infinite dilution per $2 \mathrm{e}^{-}$donated.

$\ddagger$ Based on oxidation to pyruvate.

$\S$ Estimated, taking $\lambda_{0}$ for lactate as $36 \mathrm{~S} \mathrm{~cm}^{2} \mathrm{~mol}^{-1}$.

$\|$ Retention of $\mathrm{CO}_{2}$ as $\mathrm{HCO}_{3}^{-}$has effects that are considered in detail later in the paper.
}

fermentation the major $\mathrm{H}^{+}$flux is associated with excretion of lactic acid (i.e. outward flux of $\mathrm{H}^{+}$, see Table 2) and additional outward $\mathrm{H}^{+}$flux might be obtained by the use of a positively charged fermentable substrate instead of glucose and by the use of $\mathrm{NH}_{4}^{+}$as nitrogen source rather than a neutral or negatively charged compound. A negatively charged fermentable substrate or nitrogen source should not be used since their uptake would be accompanied by uptake of $\mathrm{H}^{+}$in opposition to the excretion due to lactate production.

\section{Electron donor}

The electron donor must always be one of the major nutrients, and in fermentative cultures the electron donor and electron acceptor (which may, of course, be the same compound) are consumed in far greater quantities than other nutrients. Potentially, therefore, the electron donor has a major influence on conductivity changes in cultures.

Examples of oxidation reactions are shown in Table 4, with their associated $\mathrm{H}^{+}$fluxes and conductivity changes. These are expressed per 2-electron change in oxidation state because biological oxidations normally involve 2 -electron transfers and because, for cultures generating ATP primarily by oxidative phosphorylation, the ATP generated and amount of growth supported are approximately proportional to the reducing power generated. Thus, presentation in this way gives a better guide to the relative conductivity changes to be expected per unit biomass synthesized than would presentation of changes per mole of substrate utilized. It is evident from Table 4 that : (a) oxidation of carboxylic acids to $\mathrm{CO}_{2}$ leads to a decrease in conductivity whereas oxidation of amines or amino acids to $\mathrm{CO}_{2}$ leads to an increase in conductivity due to release of $\mathrm{NH}_{4}^{+} ;(b)$ the $\mathrm{H}^{+}$flux and conductivity change (per $2 \mathrm{e}^{-}$) are higher for electron donors at a higher oxidation state than for those at a more reduced state (cf. the series $\mathrm{HCOO}^{-}$to $\mathrm{C}_{3} \mathrm{H}_{7} \mathrm{COO}^{-}$); (c) Stickland-type oxidation of amino acids yields large increases in conductivity due to the production of organic acids and $\mathrm{NH}_{4}^{+}$.

\section{Electron acceptor}

Various electron acceptor half-reactions are shown in Table 5, from which it is evident that there are considerable differences between the reactions both in $\mathrm{H}^{+}$fluxes and in conductivity 
Table 5. Effect of external electron acceptor on $H^{+}$flux and conductivity changes in microbial cultures

Electron acceptor

$$
\begin{aligned}
& \mathrm{O}_{2}+4 \mathrm{H}^{+}+4 \mathrm{e}^{-} \rightarrow 2 \mathrm{H}_{2} \mathrm{O} \\
& \mathrm{NO}_{3}^{-}+2 \mathrm{H}^{+}+2 \mathrm{e}^{-} \rightarrow \mathrm{NO}_{2}^{-}+\mathrm{H}_{2} \mathrm{O} \\
& 2 \mathrm{NO}_{3}^{-}+12 \mathrm{H}^{+}+10 \mathrm{e}^{-} \rightarrow \mathrm{N}_{2}+6 \mathrm{H}_{2} \mathrm{O} \\
& \mathrm{NO}_{3}^{-}+10 \mathrm{H}^{+}+8 \mathrm{e}^{-} \rightarrow \mathrm{NH}_{4}^{+}+3 \mathrm{H}_{2} \mathrm{O} \\
& \mathrm{S}_{4} \mathrm{O}_{6}^{-}+2 \mathrm{e}^{-} \rightarrow 2 \mathrm{~S}_{2} \mathrm{O}_{3}^{2-} \\
& \mathrm{SO}_{4}^{-}+8 \mathrm{H}^{+}+8 \mathrm{e}^{-} \rightarrow \mathrm{S}^{2-}+4 \mathrm{H}_{2} \mathrm{O} \\
& \mathrm{CO}_{2}+8 \mathrm{H}^{+}+8 \mathrm{e}^{-} \rightarrow \mathrm{CH}_{4}+2 \mathrm{H}_{2} \mathrm{O} \\
& \mathrm{HCO}_{3}^{-}+9 \mathrm{H}^{+}+8 \mathrm{e}^{-} \rightarrow \mathrm{CH}_{4}+3 \mathrm{H}_{2} \mathrm{O} \\
& \left(\mathrm{CH}_{3}\right)_{3} \mathrm{NO}^{-}+3 \mathrm{H}^{+}+2 \mathrm{e}^{-} \rightarrow\left(\mathrm{CH}_{3}\right)_{3} \mathrm{NH}^{+}+\mathrm{H}_{2} \mathrm{O} \\
& \left(\mathrm{CHCOO}^{-}\right)_{2}+2 \mathrm{H}^{+}+2 \mathrm{e}^{-} \rightarrow\left(\mathrm{CH}_{2} \mathrm{COO}^{-}\right)_{2} \\
& \mathrm{H}_{3}^{+} \mathrm{NCH}_{2} \mathrm{COO}^{-}+2 \mathrm{H}^{+}+2 \mathrm{e}^{-} \rightarrow \mathrm{CH}_{3} \mathrm{COO}^{-}+\mathrm{NH}_{4}^{+}
\end{aligned}
$$

$$
\begin{aligned}
& \text { Net change in } \\
& \text { conductivity* } \\
& {\left[S \mathrm{~cm}^{2}\left(2 \mathrm{e}^{-}\right)^{-1}\right]}
\end{aligned}
$$$$
\left.\left(2 \mathrm{e}^{-}\right)^{-1}\right]
$$$$
0
$$$$
0
$$$$
-0 \cdot 4
$$$$
-0.5
$$$$
+2
$$$$
0
$$$$
0
$$$$
-0.25
$$$$
-1
$$$$
0
$$$$
0
$$

* Net change in conductivity at infinite dilution attributed to reduction of electron acceptor, expressed per 2 electrons accepted.

changes. Since many of the reactions shown are specific to particular microbial types, it is likely that these differences could be exploited in the design of culture media for the enumeration and/or identification of specific kinds of microbes or metabolic activities.

\section{Carbon source}

A difference between material assimilated and electron donor or acceptor compounds is that there are generally no products other than cell material. Hence, the only effect on medium conductivity is a decrease if the carbon source is charged or no change if it is not.

If a decrease in conductivity is desirable, it may be accentuated by the use of a multi-charged compound with a high charge-to-mass ratio, since such compounds tend to exhibit higher molar conductivities on a per charge basis than do compounds bearing only one charge (Table 1). However, this advantage may be lessened by a countervailing greater tendency of the multicharged compounds to ion-pair formation or metal chelation.

In cultures where a net increase in conductivity is expected the situation is more complex. Any charged compound taken up by cells influences the conductivity of the medium by two routes. Firstly, there is an inevitable reduction in conductivity due to the removal of charged ions from solution. Secondly, there is a change in the conductivity of the ions of the $\mathrm{pH}$ buffer due to $\mathrm{H}^{+}$ flux associated with uptake of the charged nutrient. Hence, preference for a neutral or a charged carbon source depends upon whether the net result of these two effects is an increase or a decrease in conductivity.

\section{Nitrogen source}

The main types of compounds used as nitrogen sources are listed in Table 6 along with the associated $\mathrm{H}^{+}$fluxes and conductivity changes. Values for the molar conductivities of the organic nitrogen sources do not appear to be available, but it may be assumed that, due to the larger sizes of the molecules, they will be considerably less than the values for $\mathrm{NH}_{4}^{+}$and $\mathrm{NO}_{3}^{-}$. Hence, conductivity decrease may be maximized by the use of $\mathrm{NH}_{4}^{+}$or $\mathrm{NO}_{3}^{-}$, whereas if no conductivity decrease is desired, an amino acid zwitterion with no net charge may be appropriate.

\section{Metabolic products}

The general effects of different metabolic products on $\mathrm{H}^{+}$flux and conductivity changes have already been indicated in the discussions on electron donors, electron acceptors, carbon sources and nitrogen sources. However, one aspect not so far considered is the fate of $\mathrm{CO}_{2}$, if produced, 
Table 6. Effect of nitrogen source on $\mathrm{H}^{+}$flux and conductivity changes in microbial cultures

\begin{tabular}{|c|c|c|}
\hline Nitrogen source & $\begin{array}{c}\mathrm{H}^{+} \text {flux } \\
{\left[\mathrm{mol} \mathrm{H^{+ } \text { out }}\right.} \\
\left.(\text { mol N-source })^{-1}\right]\end{array}$ & $\begin{array}{l}\text { Change in } \\
\text { conductivity* } \\
\left(\mathrm{S} \mathrm{cm}^{2} \mathrm{~mol}^{-1}\right)\end{array}$ \\
\hline $\begin{array}{l}\mathrm{NH}_{4}^{+} \\
\mathrm{N}_{2} \\
\mathrm{NO}_{3}^{-}\end{array}$ & $\begin{array}{r}1 \\
0 \\
-1\end{array}$ & $\begin{array}{c}-73 \cdot 5 \\
0 \\
-71 \cdot 4\end{array}$ \\
\hline $\begin{array}{l}\mathrm{H}_{3} \stackrel{+}{\mathrm{N}} \mathrm{CH}_{2} \mathrm{COO}_{+}^{-} \\
-\mathrm{OOCCH}_{2} \mathrm{CHNH}_{3} \mathrm{COO}^{-}\end{array}$ & $\begin{array}{r}0 \dagger \\
-1 \dagger\end{array}$ & $-\lambda_{A s p}^{0 \dagger} 0^{0}+$ \\
\hline $\mathrm{H}_{3} \stackrel{+}{\mathrm{N}}\left(\mathrm{CH}_{2}\right)_{4} \mathrm{CH}^{+} \stackrel{+}{\mathrm{N}} \mathrm{H}_{3} \mathrm{COO}^{-}$ & $1 \dagger$ & $-\lambda_{\mathrm{Lys}}^{0} \dagger$ \\
\hline
\end{tabular}

* Net change in conductivity at infinite dilution attributed to assimilation of nitrogen source.

$\dagger$ Assumes that the carbon moiety is assimilated.

Table 7. Calculated concentrations of $\mathrm{CO}_{2}, \mathrm{HCO}_{3}^{-}$and $\mathrm{CO}_{3}^{2-}$ present in solutions of different $\mathrm{pH}$ values in equilibrium with air

The concentrations were calculated taking $P_{\mathrm{CO}}$ in air $=10^{-3 \cdot 5} \mathrm{~atm}, K_{\mathrm{H}}=10^{-1 \cdot 47}, K_{1}^{\mathrm{C}}=10^{-6 \cdot 35}$, and $K_{2}^{\mathrm{C}}=10^{-10 \cdot 33}$ at $25^{\circ} \mathrm{C}$.

$\begin{array}{rccc}\mathrm{pH} & \begin{array}{c}{\left[\mathrm{CO}_{2}\right]} \\ \left(\mathrm{mol}^{-1}\right)\end{array} & \begin{array}{c}{\left[\mathrm{HCO}_{3}^{-}\right]} \\ \left(\mathrm{mol} \mathrm{l}^{-1}\right)\end{array} & \begin{array}{c}{\left[\mathrm{CO}_{3}^{2-}\right]} \\ \left(\mathrm{mol} \mathrm{l}^{-1}\right)\end{array} \\ 3 & 1.07 \times 10^{-5} & 4.8 \times 10^{-9} & 2.2 \times 10^{-16} \\ 5 & 1.07 \times 10^{-5} & 4.8 \times 10^{-7} & 2.2 \times 10^{-12} \\ 7 & 1.07 \times 10^{-5} & 4.8 \times 10^{-5} & 2.2 \times 10^{-8} \\ 8 & 1.07 \times 10^{-5} & 4.8 \times 10^{-4} & 2.2 \times 10^{-6} \\ 9 & 1.07 \times 10^{-5} & 4.8 \times 10^{-3} & 2.2 \times 10^{-4} \\ 10 & 1.07 \times 10^{-5} & 4.8 \times 10^{-2} & 2.2 \times 10^{-2}\end{array}$

and its possible effects on $\mathrm{H}^{+}$flux and conductivity change. There are three possible fates for $\mathrm{CO}_{2}$ produced within cultures: $(a)$ it is released into the atmosphere, $(b)$ it remains in solution as dissolved $\mathrm{CO}_{2},(c)$ it is hydrolysed partially or completely to bicarbonate: $\mathrm{CO}_{2}+\mathrm{H}_{2} \mathrm{O} \rightleftharpoons$ $\mathrm{HCO}_{3}^{-}+\mathrm{H}^{+}$. Fates $(a)$ and $(b)$ have no effect on $\mathrm{H}^{+}$flux or conductivity but formation of $\mathrm{HCO}_{3}^{-}$ has effects on both. Which of these three fates befalls the $\mathrm{CO}_{2}$ in cultures depends upon whether the system is sealed or open to the atmosphere and upon the $\mathrm{pH}$ value of the medium.

$\mathrm{CO}_{2}$ equilibria in media open to the atmosphere. The basic relationships at equilibrium are described by Butler (1982):

$$
\begin{aligned}
{\left[\mathrm{CO}_{2}\right] } & =K_{\mathrm{H}} P_{\mathrm{CO}_{2}}=10^{-4 \cdot 97} \\
{\left[\mathrm{HCO}_{3}^{-}\right] } & =\frac{K_{1}^{\mathrm{C}} K_{\mathrm{H}} P_{\mathrm{CO}_{2}}}{\left[\mathrm{H}^{+}\right]}=\frac{10^{-11 \cdot 32}}{\left[\mathrm{H}^{+}\right]} \\
{\left[\mathrm{CO}_{3}^{2-}\right] } & =\frac{K_{2}^{\mathrm{C}} K_{1}^{\mathrm{C}} K_{\mathrm{H}} P_{\mathrm{CO}_{2}}}{\left[\mathrm{H}^{+}\right]^{2}}=\frac{10^{-21 \cdot 65}}{\left[\mathrm{H}^{+}\right]^{2}}
\end{aligned}
$$

where $\left[\mathrm{CO}_{2}\right]$ is the concentration of $\mathrm{CO}_{2}$ in solution $\left(\mathrm{mol} \mathrm{l}^{-1}\right)$ (some $\mathrm{CO}_{2}$ is present as $\mathrm{H}_{2} \mathrm{CO}_{3}$, but since $\left[\mathrm{H}_{2} \mathrm{CO}_{3}\right]$ is only $10^{-3}$ of $\left[\mathrm{CO}_{2}\right],\left[\mathrm{CO}_{2}\right]+\left[\mathrm{H}_{2} \mathrm{CO}_{3}\right]$ is referred to as $\left.\left[\mathrm{CO}_{2}\right]\right), P_{\mathrm{CO}_{2}}$ is the partial pressure of $\mathrm{CO}_{2}$ in the atmosphere $\left(10^{-3.5}\right.$ atm in air), $K_{\mathrm{H}}$ is Henry's Law constant $\left(10^{-1.47} \mathrm{~mol} \mathrm{l}^{-1} \mathrm{~atm}^{-1}\right.$ at $\left.25^{\circ} \mathrm{C}\right),\left[\mathrm{HCO}_{3}^{-}\right]$is the concentration of $\mathrm{HCO}_{3}^{-}$in solution, $\left[\mathrm{CO}_{3}^{2-}\right]$ is the concentration of $\mathrm{CO}_{3}^{2-}$ in solution, $K_{1}^{\mathrm{C}}$ is the first dissociation constant for carbonic acid $\left(10^{-6.35}\right.$ at $25^{\circ} \mathrm{C}$ ), and $K_{2}^{\mathrm{C}}$ is the second dissociation constant for carbonic acid $\left(10^{-10.33}\right.$ at $\left.25^{\circ} \mathrm{C}\right)$.

Thus the concentration of $\mathrm{CO}_{2}$ in solution is independent of $\mathrm{pH}$ while the concentrations of $\mathrm{HCO}_{3}^{-}$and $\mathrm{CO}_{3}^{2-}$ are $\mathrm{pH}$ dependent. Nevertheless, it is evident that the concentrations of all 
Table 8. Effect of $\mathrm{pH}$ on the proportions of total carbonate present as $\mathrm{CO}_{2}, \mathrm{HCO}_{3}^{-}$and $\mathrm{CO}_{3}^{2-}$ in solution in a closed container without a gas phase

\begin{tabular}{|c|c|c|c|}
\hline \multirow[b]{2}{*}{$\mathrm{pH}$} & \multicolumn{3}{|c|}{$\begin{array}{l}\text { Proportion of total carbonate } \\
\text { present as }\end{array}$} \\
\hline & $\mathrm{CO}_{2}$ & $\mathrm{HCO}_{3}^{-}$ & $\mathrm{CO}_{3}^{2-}$ \\
\hline 3 & $\sim 1.0$ & $\sim 0$ & $\sim 0$ \\
\hline 4 & $\sim 1.0$ & $\sim 0$ & $\sim 0$ \\
\hline 5 & 0.96 & 0-04 & $\sim 0$ \\
\hline 6 & 0.69 & 0.31 & $\sim 0$ \\
\hline 7 & 0.18 & 0.82 & $\sim 0$ \\
\hline 8 & 0.02 & 0.97 & 0.01 \\
\hline 9 & $\sim 0$ & 0.95 & 0.05 \\
\hline 10 & $\sim 0$ & 0.68 & 0.32 \\
\hline
\end{tabular}

three in equilibrium with the concentration of $\mathrm{CO}_{2}$ in air are so low at the usual $\mathrm{pH}$ values of microbial cultures that the contributions of $\mathrm{HCO}_{3}^{-}$and $\mathrm{CO}_{3}^{2-}$ to $\mathrm{H}^{+}$flux and conductivity changes will generally be negligible (Table 7). However, it should be borne in mind that culture media may not be in equilibrium with atmospheric $\mathrm{CO}_{2}$, or may not attain equilibrium rapidly.

$\mathrm{CO}_{2}$ equilibria in media in closed vessels without a gas phase. Under these conditions, the concentrations of the different species are given by the following relationships (Butler, 1982):

$$
\begin{gathered}
{\left[\mathrm{CO}_{2}\right]=C_{\mathrm{T}}^{\mathrm{C}}\left(\frac{\left[\mathrm{H}^{+}\right]^{2}}{K_{1}^{\mathrm{C}} K_{2}^{\mathrm{C}}+K_{1}^{\mathrm{C}}\left[\mathrm{H}^{+}\right]+\left[\mathrm{H}^{+}\right]^{2}}\right)} \\
{\left[\mathrm{HCO}_{3}^{-}\right]=C_{\mathrm{T}}^{\mathrm{C}}\left(\frac{K_{1}^{\mathrm{C}}\left[\mathrm{H}^{+}\right]}{K_{1}^{\mathrm{C}} K_{2}^{\mathrm{C}}+K_{1}^{\mathrm{C}}\left[\mathrm{H}^{+}\right]+[\mathrm{H}]^{2}}\right)} \\
{\left[\mathrm{CO}_{3}^{2-}\right]=C_{\mathrm{T}}^{\mathrm{c}}\left(\frac{K_{1}^{\mathrm{C}} K_{2}^{\mathrm{C}}}{K_{1}^{\mathrm{C}} K_{2}^{\mathrm{C}}+K_{1}^{\mathrm{C}}\left[\mathrm{H}^{+}\right]+\left[\mathrm{H}^{+}\right]^{2}}\right)}
\end{gathered}
$$

where $C$ T is the total concentration of carbonate present (i.e. $\left.\left[\mathrm{CO}_{2}\right]+\left[\mathrm{HCO}_{3}^{-}\right]+\left[\mathrm{CO}_{3}^{2-}\right]\right)$. Thus, for a given $\mathrm{pH}$ value, the amount of each species is a constant proportion of the total carbonate carbon present. These proportions, and how they change with $\mathrm{pH}$, are shown in Table 8 . It is clear that $\mathrm{CO}_{3}^{2-}$ can generally be ignored in cultures and that, so far as effects on conductivity and $\mathrm{H}^{+}$flux are concerned, only the concentration of $\mathrm{HCO}_{3}^{-}$is of consequence. The $\mathrm{pH}$ of cultures following the production of a given amount of $\mathrm{CO}_{2}$ is calculated as indicated earlier, and appropriate allowance is then easily made for the conductivity due to $\mathrm{HCO}_{3}^{-}$.

$\mathrm{CO}_{2}$ equilibria in media in closed vessels with a gas phase. For a closed vessel containing $V_{\mathrm{L}}$ litres of culture medium with a concentration of $\mathrm{CO}_{2}$ in solution of $\left[\mathrm{CO}_{2}\right]_{\mathrm{L}} \mathrm{mol} \mathrm{l}^{-1}$, and a gas phase of $V_{\mathrm{G}}$. litres with a partial pressure of $\mathrm{CO}_{2}$ of $\mathrm{P}_{\mathrm{CO}_{2}}$ atm, the basic relationships are:

$$
\begin{gathered}
{\left[\mathrm{CO}_{2}\right]_{\mathrm{L}}=K_{\mathrm{H}} P_{\mathrm{CO}_{2}}} \\
{\left[\mathrm{CO}_{2}\right]_{\mathrm{L}}=\frac{\left[\mathrm{HCO}_{3}^{-}\right]\left[\mathrm{H}^{+}\right]}{K_{1}^{\mathrm{C}}}} \\
C_{\mathrm{T}}=C_{\mathrm{G}}^{\mathrm{CO}_{2}}+C_{\mathrm{L}}^{\mathrm{CO}_{2}}+C_{\mathrm{L}}^{\mathrm{HCO}_{3}^{-}}+C_{\mathrm{L}}^{\mathrm{CO}_{3}^{2-}}
\end{gathered}
$$


where $C_{\mathrm{T}}$ is the total amount of $\mathrm{CO}_{2}+\mathrm{HCO}_{3}^{-}+\mathrm{CO}_{3}^{2-}$ in the vessel, $C_{\mathrm{G}} \mathrm{CO}_{2}$ is the amount of $\mathrm{CO}_{2}$ in the gas phase $(\mathrm{mol}), C_{\mathrm{L}}^{\mathrm{CO}_{2}}$ is the amount of $\mathrm{CO}_{2}$ in the liquid phase $(\mathrm{mol}), C_{\mathrm{L}}^{\mathrm{HCO}}{ }_{3}^{-}$is the amount of $\mathrm{HCO}_{3}^{-}$in solution (mol), and $C_{\mathrm{L}}^{\mathrm{HCO}_{3}^{2-}}$ is the amount of $\mathrm{CO}_{3}^{2-}$ in solution (mol). Thus:

$$
\begin{gathered}
C_{\mathrm{T}}=P_{\mathrm{Co}_{2}} V_{\mathrm{G}} / V_{\mathrm{m}}+\left[\mathrm{CO}_{2}\right]_{\mathrm{L}} V_{\mathrm{L}}+\left[\mathrm{HCO}_{3}^{-}\right] V_{\mathrm{L}}+\left[\mathrm{CO}_{3}^{2-}\right] V_{\mathrm{L}} \\
P_{\mathrm{Co}_{2}}=\frac{\left[\mathrm{HCO}_{3}^{-}\right]\left[\mathrm{H}^{+}\right]}{K_{1}^{\mathrm{C}} K_{\mathrm{H}}}
\end{gathered}
$$

For $\mathrm{pH}$ below $9, \mathrm{CO}_{3}^{2-}$ can be neglected, and:

$$
C_{\mathrm{T}}=\frac{\left[\mathrm{HCO}_{3}^{-}\right]\left[\mathrm{H}^{+}\right] V_{\mathrm{G}}}{V_{\mathrm{m}} K_{1}^{\mathrm{C}} K_{\mathrm{H}}}+\frac{\left[\mathrm{HCO}_{3}^{-}\right]\left[\mathrm{H}^{+}\right] \mathrm{V}_{\mathrm{L}}}{K_{1}^{\mathrm{C}}}+\left[\mathrm{HCO}_{3}^{-}\right] V_{\mathrm{L}}
$$

where $V_{\mathrm{m}}$ is the molar volume of an ideal gas at $1 \mathrm{~atm}$ and $25^{\circ} \mathrm{C}\left(24.471 \mathrm{~mol}^{-1}\right)$.

Dividing by $V_{\mathrm{L}}$ :

$$
\frac{C_{\mathrm{T}}}{V_{\mathrm{L}}}=\frac{\left[\mathrm{HCO}_{3}^{-}\right]\left[\mathrm{H}^{+}\right] V_{\mathrm{G}}}{V_{\mathrm{m}} K_{1}^{\mathrm{C}} K_{\mathrm{H}} V_{\mathrm{L}}}+\frac{\left[\mathrm{HCO}_{3}^{-}\right]\left[\mathrm{H}^{+}\right]}{K_{1}^{\mathrm{C}}}+\left[\mathrm{HCO}_{3}^{-}\right]
$$

If we put $V_{\mathrm{L}}=1$ and $V_{\mathrm{G}} / V_{\mathrm{L}}=V_{\mathrm{R}}$, where $V_{\mathrm{R}}$ is the ratio of volume of gas phase to volume of liquid phase in the vessel, then:

$$
C_{\mathrm{T}}=\left[\mathrm{HCO}_{3}^{-}\right]\left(\frac{\left[\mathrm{H}^{+}\right] V_{\mathrm{R}}}{V_{\mathrm{m}} K_{1}^{\mathrm{C}} K_{\mathrm{H}}}+\frac{\left[\mathrm{H}^{+}\right]}{K_{1}^{\mathrm{C}}}+1\right)
$$

and

$$
\begin{aligned}
{\left[\mathrm{HCO}_{3}^{-}\right] } & =C_{\mathrm{T}}\left(\frac{V_{\mathrm{m}} K_{1}^{\mathrm{C}} K_{\mathrm{H}}}{V_{\mathrm{m}} K_{1}^{\mathrm{c}} K_{\mathrm{H}}+V_{\mathrm{m}} K_{\mathrm{H}}\left[\mathrm{H}^{+}\right]+\left[\mathrm{H}^{+}\right] V_{\mathrm{R}}}\right) \\
& =\alpha C_{\mathrm{T}}
\end{aligned}
$$

where $\alpha$ equals the term in round brackets.

And, since $V_{\mathrm{L}}=1$ and $V_{\mathrm{G}}=V_{\mathrm{R}}$ :

$$
\begin{aligned}
C_{\mathrm{L}}^{\mathrm{HCO}_{3}^{-}} & =\left[\mathrm{HCO}_{3}^{-}\right] \\
C_{\mathrm{L}}^{\mathrm{CO}_{2}} & =\left[\mathrm{CO}_{2}\right]_{\mathrm{L}}=\frac{\left[\mathrm{HCO}_{3}^{-}\right]\left[\mathrm{H}^{+}\right]}{K_{1}^{\mathrm{C}}} \\
C_{\mathrm{G}^{2}}^{\mathrm{CO}_{2}} & =C_{\mathrm{T}}-C_{\mathrm{L}}^{\mathrm{CO}_{2}}-C_{\mathrm{L}}^{\mathrm{HCO}_{3}^{-}} \\
& =C_{\mathrm{T}}-\left[\mathrm{HCO}_{3}^{-}\right]\left(\frac{\left[\mathrm{H}^{+}\right]}{K_{1}^{\mathrm{C}}}+1\right)
\end{aligned}
$$

And the proportions of the total represented by each species are given by:

$$
\begin{aligned}
C_{\mathrm{L}}^{\mathrm{HCO}_{3}} / C_{\mathrm{T}} & =\alpha \\
C_{\mathrm{L}}^{\mathrm{CO}_{2}} / C_{\mathrm{T}} & =\alpha\left[\mathrm{H}^{+}\right] / K_{1}^{\mathrm{C}} \\
C_{\mathrm{G}}^{\mathrm{CO}_{2}} / C_{\mathrm{T}} & =1-\alpha\left\{\left(\left[\mathrm{H}^{+}\right] / K_{1}^{\mathrm{C}}\right)+1\right\}
\end{aligned}
$$

The calculated relative proportions of each species for different gas volume to liquid volume ratios are shown in Table 9. It is evident that, even with a large gaseous phase, a substantial proportion $(25 \%$ at $\mathrm{pH} 7$ with a gas:liquid ratio of $10: 1)$ of the total carbonate in a closed container can be in the form of $\mathrm{HCO}_{3}^{-}$if the $\mathrm{pH}$ is near or above neutrality.

Strategies for $\mathrm{CO}_{2} / \mathrm{HCO}_{3}^{-}$production in culture media. Apart from the direct contribution of $\mathrm{HCO}_{3}^{-}$to conductivity, the formation of $\mathrm{HCO}_{3}^{-}$is accompanied by the production $\mathrm{H}^{+}$(i.e. 
Table 9. Effect of ratio of volume of gas phase to volume of liquid phase and $\mathrm{pH}$ value on the relative proportions of gaseous $\mathrm{CO}_{2}$, dissolved $\mathrm{CO}_{2}$ and $\mathrm{HCO}_{3}^{-}$in a closed vessel

\begin{tabular}{|c|c|c|c|c|}
\hline \multirow[b]{2}{*}{$\mathrm{pH}$} & \multirow[b]{2}{*}{$\begin{array}{l}\text { Volume of gas phase/ } \\
\text { volume of liquid }\end{array}$} & \multicolumn{3}{|c|}{ Proportion of total $\mathrm{CO}_{2}$ as*: } \\
\hline & & $\mathrm{HCO}_{3}^{-}$ & $\begin{array}{c}\text { Dissolved } \\
\mathrm{CO}_{2}\end{array}$ & $\begin{array}{c}\text { Gaseous } \\
\mathrm{CO}_{2}\end{array}$ \\
\hline 5 & $\begin{array}{r}30 \\
10 \\
3 \\
1\end{array}$ & $\begin{array}{l}\sim 0 \\
\sim 0 \\
0.01 \\
0.02\end{array}$ & $\begin{array}{l}0.03 \\
0.08 \\
0 \cdot 21 \\
0.44\end{array}$ & $\begin{array}{l}0.97 \\
0.92 \\
0.78 \\
0.54\end{array}$ \\
\hline 6 & $\begin{array}{r}30 \\
10 \\
3 \\
1\end{array}$ & $\begin{array}{l}0.01 \\
0.03 \\
0.09 \\
0.17\end{array}$ & $\begin{array}{l}0.03 \\
0.08 \\
0.20 \\
0.38\end{array}$ & $\begin{array}{l}0.96 \\
0.89 \\
0.71 \\
0.45\end{array}$ \\
\hline 7 & $\begin{array}{r}30 \\
10 \\
3 \\
1\end{array}$ & $\begin{array}{l}0.11 \\
0.25 \\
0.49 \\
0.67\end{array}$ & $\begin{array}{l}0.02 \\
0.06 \\
0.11 \\
0.15\end{array}$ & $\begin{array}{l}0.87 \\
0.69 \\
0.40 \\
0.18\end{array}$ \\
\hline 8 & $\begin{array}{r}30 \\
10 \\
3 \\
1\end{array}$ & $\begin{array}{l}0.55 \\
0.77 \\
0.91 \\
0.95\end{array}$ & $\begin{array}{l}0 \cdot 01 \\
0 \cdot 02 \\
0 \cdot 02 \\
0 \cdot 02\end{array}$ & $\begin{array}{l}0.44 \\
0.21 \\
0.07 \\
0.03\end{array}$ \\
\hline
\end{tabular}

outward $\mathrm{H}^{+}$flux). Hence, if the major $\mathrm{H}^{+}$flux is inward, then retention of $\mathrm{CO}_{2}$ as $\mathrm{HCO}_{3}^{-}$is not desirable and the culture should be open to the atmosphere and/or maintained at a $\mathrm{pH}$ near or below 5 .

If the major anticipated $\mathrm{H}^{+}$flux is outward, retention of $\mathrm{CO}_{2}$ as $\mathrm{HCO}_{3}^{-}$is desirable to accentuate the flux. This may be achieved by the following means.

(a) Keeping cultures tightly sealed to prevent escape of $\mathrm{CO}_{2}$ to the atmosphere.

(b) Maintaining the $\mathrm{pH}$ of cultures near neutrality or higher, when virtually all the dissolved carbonate will be present at $\mathrm{HCO}_{3}^{-}$(Table 8).

(c) Providing the smallest possible gas space in anaerobic cultures. Since production of $\mathrm{CO}_{2}$ leads to an increase in pressure, it may be advisable to restrict the initial nutrient concentrations to control this. For example, the generation of $0 \cdot 1 \mathrm{M}-\mathrm{CO}_{2}$ in a sealed vessel without a gas phase would exert a partial pressure of nearly $3 \mathrm{~atm}$ at $25^{\circ} \mathrm{C}$ at $\mathrm{pH}$ values below about 5 .

(d) Providing the minimum gas phase in aerobic cultures that is commensurate with the provision of sufficient $\mathrm{O}_{2}$ for growth. For example, the complete oxidation of $0.75 \mathrm{~g}$ glucose $\mathrm{l}^{-1}$ requires approximately 3 volumes of air per volume of medium at $25^{\circ} \mathrm{C}$. At pH 7 half of the $\mathrm{CO}_{2}$ formed would be in solution in the medium as $\mathrm{HCO}_{3}^{-}$(Table 9). Hence, it would be useful to use a closed vessel containing this proportion of air providing that the culture $\mathrm{pH}$ could be kept near neutrality or higher. With $7.5 \mathrm{~g}$ glucose $\mathrm{1}^{-1}, 30$ volumes of air are required per volume of medium and the proportion of the $\mathrm{CO}_{2}$ that remains in solution as $\mathrm{HCO}_{3}^{-}$is then much less unless the $\mathrm{pH}$ value is near 8 or above. Nevertheless, in the absence of other sources of conductivity changes, the retention of even a small proportion of the $\mathrm{CO}_{2}$ as $\mathrm{HCO}_{3}^{-}$might be sufficient to generate a detectable conductivity change. In aerobic cultures, pressure changes are not liable to present any hazard since $\mathrm{O}_{2}$ is consumed and partially replaced by $\mathrm{CO}_{2}$.

These strategies for maximizing the conductivity changes by retention of $\mathrm{CO}_{2} / \mathrm{HCO}_{3}^{-}$in cultures assume that the microbial metabolism is unaffected by high concentrations of these compounds. It should be appreciated that this may not always be the case and that changes in the metabolic products formed could nullify or enhance the effects sought.

\section{Other inorganic nutrients}

The other inorganic nutrients consumed by cells during growth are required in relatively small amounts and their consumption has a correspondingly small effect on the overall conductivity 
change (Table 2). Hence, little consideration needs to be given to the selection of the particular salts. However, to reduce ion-pair formation effects it may be worthwhile to use uni-univalent salts rather than uni-bivalent salts where possible.

\section{Other metabolic activities}

The major activity to be considered under this heading is the breakdown of polymers. Increases in the conductivity of cultures are commonly attributed to the breakdown of polymers to smaller molecules (e.g. Eden \& Eden, 1984) but the precise mechanisms involved are not obvious.

In the case of sugar polymers hydrolysis will yield only uncharged sugar molecules and no change in conductivity would be anticipated. With a polymer such as pectin (polygalacturonic acid) an increase in conductivity would occur on hydrolysis due to the greater mobility of the monomer molecules. However, its extent would depend upon the degree to which monomers accumulate or are metabolized by the microbes.

Similarly, the hydrolysis of triglyceride fats to glycerol and free fatty acids would be expected to lead to an increase in conductivity. However, there do not appear to be reports of studies on conductivity changes associated with fat metabolism.

The polymers whose breakdown has received most attention are the proteins and peptides that occur in most complex microbiological culture media. These compounds bear some net charge themselves and thus make a contribution to carrying current, but since the molecules are large, and have relatively small net charges at the $\mathrm{pH}$ values of cultures, this contribution is small. Hydrolysis to individual amino acids will probably lead to some increase in conductivity, but the increase may not be large since most amino acids are zwitterions of the form $\mathrm{H}_{3} \mathrm{NRCOO}^{-}$and bear no net charge at $\mathrm{pH}$ values about 4 to 8 (Mahler \& Cordes, 1971). The only amino acids carrying net charges in this $\mathrm{pH}$ range are cysteine, cystine and the dicarboxylic and basic ones, namely glutamate, aspartate, lysine, hydroxylysine, arginine and histidine. It follows that conductivity changes due to polypeptide hydrolysis might be maximized by the use of proteins rich in these amino acids, or of appropriate synthetic polypeptides. However, in vigorously growing cultures the amino acids may not accumulate, due to their rapid utilization by the microbes. In such a case, nitrogen that is surplus to biosynthetic needs will be excreted into the medium as $\mathrm{NH}_{4}^{+}$, with a concomitant increase in medium conductivity. When amino acids serve as carbon sources and electron donors in aerobic metabolism the excretion of $\mathrm{NH}_{4}^{+}$ must be substantial (Table 4) and it is even greater with microbes, such as the clostridia, that are able to ferment amino acids. In the latter case the increase in conductivity is further enhanced by the formation of organic acids (Tables 4 and 5). Parsons \& Sturges (1926) suggested that the increase in conductivity observed in clostridial cultures could be entirely accounted for by the $\mathrm{NH}_{4}^{+}$formed. Thus, it seems very probable that the major mechanism by which increases in conductivity occur in carbohydrate-free peptone-containing culture media involves the formation of highly mobile $\mathrm{NH}_{4}^{+}$ions, rather than the production of largely non-conducting amino acid molecules. It follows that the amount of $\mathrm{NH}_{4}^{+}$excreted during aerobic metabolism, and the conductivity increase, may be maximized by the use of polypeptides or amino acids with high nitrogen-to-carbon ratios.

\section{General considerations}

Apart from the nature of the specific metabolic activities of the microbes, the conductivity of ions in solution is influenced by a number of general factors. The effects of these factors may be small or entirely negligible or may not be amenable to manipulation by culture medium formulation. Nevertheless, they should be borne in mind when culture media for conductimetric assays are formulated.

(a) The molar conductivities of small ions, with some exceptions among very small ones, are normally greater on a per charge basis than those of larger ions (Table 1) and in the absence of specific information on the conductivities of compounds this relationship can be assumed.

(b) The molar conductivities of multi-charged ions are normally proportionately greater on a per charge basis than those of uni-charged compounds (Table 1). This suggests that, where a 
large conductance change is desired, it would be advantageous, for example, to use a $\mathrm{B}^{3-} / \mathrm{BH}^{2-}$ or $\mathrm{B}^{2-} / \mathrm{BH}^{-}$rather than a $\mathbf{B}^{-} / \mathbf{B H}^{0}$ buffer compound.

(c) Ion-pair formation, and the consequent removal of ions from current carrying, is greater with multi-charged ions than with singly-charged ones. Thus, once the nutritional requirements for sulphur and phosphorus are satisfied, metal salts should preferably be supplied as chlorides rather than as sulphates or phosphates. The possible occurrence of ion-pair formation also suggests that, in some cases, a $\mathrm{B}^{-} / \mathbf{B H}^{0}$ buffer might yield a larger conductivity change than $\mathrm{B}^{2-} / \mathrm{BH}^{-}$or $\mathrm{B}^{3-} / \mathrm{BH}^{2-}$ buffers. This contradicts the suggestion above that larger conductivity changes would be expected with multi-charged buffers than with singly-charged ones. In practice, it is not easy to predict whether the benefits of multiple charges will be outweighed by ion-pair formation. However, since data on the molar conductivities at infinite dilution of buffers are available, or may be determined, whereas the effects of ion-pair formation are not readily evaluated, it would seem preferable to base the selection of buffers initially on their molar conductivities at infinite dilution. In addition, large multi-charged molecules may chelate metal ions, and similar kinds of considerations apply as just discussed for ion-pair formation.

(d) The higher the total ionic strength of the medium, the greater is the depression of the molar conductivities of the constituent ions from their values at infinite dilution. Hence, absolute and percentage changes in conductivity will be greater in media of low ionic strength than in those of high ionic strength. The ionic strength of media could be minimized by using minimal concentrations of nutrients and by using singly-charged ions in preference to multi-charged ones.

(e) Viscosity has a major effect on the mobilities of ions in solution and hence on the conductivity of solutions. However, the effect is small at the molecular concentrations existing in most culture media, and the effects on conductivity of changes in viscosity during microbial growth are likely to be negligible. The addition of low concentrations (about $0 \cdot 1-0 \cdot 2 \%$ ) of agar to liquid culture media is helpful to stabilize media-test sample mixtures in cases where the slow sedimentation of particles or separation of emulsions would cause base-line drift or product interference with the conductance signal independent of microbial growth (Malthus Instruments, personal communication). Such concentrations of agar have a negligible effect on the conductivity of culture media (author's unpublished observations). Curtis et al. (1985) recommended the use of dextran, $4 \mathrm{~g} \mathrm{l}^{-1}$, in blood cultures to eliminate the signal due to erythrocyte sedimentation. They reported that neither 4 nor $40 \mathrm{~g}$ dextran $1^{-1}$ had any significant effect on the rates of conductivity changes in broth cultures.

\section{RATE OF CHANGE OF CONDUCTIVITY WITH TIME}

The preceding discussions have concentrated upon ways of maximizing the total change in conductivity associated with microbial growth without giving attention to whether the change occurs rapidly or slowly. However, in routine conductimetric microbiological assays speed is important.

The rate of conductivity change in a growing culture will, other things being equal, depend upon both the net conductivity change per unit biomass produced and the rate of growth of that biomass. Microbial growth is generally fastest in complex media which contain many nutrients in ready-made form. Such media are inherently relatively non-specific with regard to the metabolic activities that can occur, whereas simpler media may 'lock' an organism into a particular type of metabolism. Hence, there is a potential conflict in the formulation of media for conductimetric assays between a desire to use complex media to promote rapid growth and a desire to use simple media that 'lock' the microbes into pathways that maximize conductivity changes. The exact balance between these two ideals would depend upon the particular application and priorities.

\section{EXPERIMENTAL STUDIES}

The experimental investigation of the mechanisms of conductivity changes in microbial cultures depends upon having sufficiently simple and well-defined systems in which the 
Table 10. Experimentally determined and theoretical changes in conductivity of cultures of E. coli $\mathrm{K} 12$ grown in different culture media

Cultures were grown in a defined mineral salts medium containing $0.02 \mathrm{M}$-buffer and sufficient carbon source to support approximately $100 \mathrm{mg}$ dry biomass $\mathrm{l}^{-1}$.

$\begin{array}{cllcc}\begin{array}{c}\text { Carbon } \\ \text { source }\end{array} & \begin{array}{c}\text { Growth } \\ \text { conditions }\end{array} & \begin{array}{c}\mathrm{pH} \\ \text { buffer }\end{array} & \overbrace{\text { Predicted }}^{\text {Change in conductivity }} \begin{array}{c}\text { Observed } \\ \left(\mu \mathrm{sm}^{-1}\right)\end{array} \\ \text { Glucose } & \text { Aerobic } & \text { Phosphate } & -180 & -110 \\ \text { Glucose } & \text { Anaerobic } & \text { Phosphate } & -370 & -190 \\ \text { Glucose } & \text { Anaerobic } & \text { Tris } & +? \dagger & +410 \\ \text { Glucose } & \text { Anaerobic } & \text { Histidine } & +? \dagger & +470 \\ \text { Alanine } & \text { Aerobic } & \text { Phosphate } & +360 & +280\end{array}$

* Predicted values were calculated as described in the text and are corrected for the approximate proportions of $\mathrm{CO}_{2}$ and $\mathrm{HCO}_{3}^{-}$existing in the cultures at their final $\mathrm{pH}$ values.

$\dagger$ An increase in conductivity is predicted but cannot be quantified due to lack of data on the molar conductivity of the buffer.

metabolic activities of the microbes are controlled and known. Such an approach was used by Owens et al. (1985) in a study on the conductivity changes during the oxidation of formate by non-growing cell suspensions of Escherichia coli with trimethylamine oxide as final electron acceptor. That the metabolism was 'locked' into the intended reactions was shown by the close agreement between observed and predicted changes in $\mathrm{pH}$. Clear evidence was obtained that a major proportion of the conductivity change associated with the oxidation-reduction was due to the conversion of dihydrogen phosphate buffer to hydrogen phosphate, as predicted from theoretical considerations. Hence, the work of Owens et al. (1985) supports the validity of the general approach and model presented in this paper. In particular, it confirms the thesis that the $\mathrm{pH}$ buffer is potentially one of, if not the most, important sources of conductivity changes in microbial cultures and emphasizes that selection of an appropriate $\mathrm{pH}$ buffer system is crucial in attempts to maximize conductivity changes in cultures.

An effect of the $\mathrm{pH}$ buffer has also been reported by Malthus Instruments (personal communication). During the development of the Malthus Coliform Medium it was noted that the conductivity change produced by microbial growth was greater in the presence of Tris buffer than with phosphate buffer. This is readily understood in lactose-fermenting and acidproducing cultures. As pointed out above, the conductivity of Tris buffer increases with decline in $\mathrm{pH}$ and thus aids the increase in conductivity due to the formation of acids, whereas the conductivity of phosphate decreases with decline in $\mathrm{pH}$ and counteracts the increase associated with acid production. The data presented in Table 10 are also in accordance with this explanation. The fermentation of glucose by $E$. coli in a mineral salts medium containing phosphate buffer was accompanied by a decrease in conductivity of the medium whereas an increase in conductivity occurred with Tris or histidine buffers.

Comparison of experimentally observed changes in the conductivity of cultures in different media with the changes predicted by calculation (Table 10) shows that all the observed changes are in the predicted directions and that their magnitudes are substantially less than the calculated values. The observed changes are expected to be less than theoretical changes calculated using molar conductivities at infinite dilution, for the reasons indicated previously, but the extent of this difference cannot be estimated precisely. The conductivity changes observed range from 51 to $78 \%$ of the calculated values and would appear to be reasonable for media having a total ion concentration of $0.05-0.07 \mathrm{moll}^{-1}$. In those cases where the discrepancy is especially large, it is probable that this is due to the formation of metabolic products different from those assumed in the calculations. For future studies, accuracy might be improved by using media containing a minimum of multi-charged ions, to minimize interionic interactions, and assaying the metabolic products formed in the cultures. 


\section{CONCLUSIONS}

To date, the selection of culture media for conductimetric microbiological assays has been an empirical, trial-and-error procedure, expensive in both time and effort. Even when an apparently satisfactory medium is found, its reliability cannot be assumed in all circumstances, due to lack of knowledge of the mechanisms involved. Since conductivity changes can differ between even closely related reactions (Owens et al., 1985), highly specific conductimetric assays cannot be designed without a full understanding of the sources of conductivity changes in cultures.

The model of conductivity changes in microbial cultures presented in this paper allows the direction and relative rates of the changes to be predicted from theoretical calculations. This should permit the rational design of media for the enumeration of specific categories of microbes, for the identification of species, or for assessment of particular enzyme activities. The development of such media, combined with the simplicity of the basic methodology, will ensure the increasing application of conductimetric techniques to routine microbiological and biochemical assays.

The author thanks Mrs C. Wacher-Viveros for excellent assistance with the computer programming and for help in other parts of the work, and Dr A. D. Pethybridge for much valuable advice on aspects of conductivity and for reading and commenting upon the manuscript.

\section{REFERENCES}

Allison, J. B., Anderson, J. A. \& Cole, W. H. (1938). The method of electrical conductivity in studies on bacterial metabolism. Journal of Bacteriology 36, 571-586.

BOCKRIS, J. O. \& REDDY, A. K. N. (1970). Modern Electrochemistry, vol. I. London: Macdonald.

ButLer, J. N. (1982). Carbon Dioxide Equilibria and their Appilcations. Keading, Mass. : Addison-Wesley.

CADY, P. (1975). Rapid automated bacterial identification by impedance measurement. In New Approaches to the Identification of Microorganisms, pp. 73-99. Edited by C. G. Hedén \& T. Illéni. New York: Wiley.

Curtis, G. D. W., Thomas, C. D. \& Johnston, H. H. (1985). A note on the use of dextran in blood cultures monitored by conductance methods. Journal of Applied Bacteriology 58, 571-575.

Conway, B. E. (1952). Electrochemical Data. Amsterdam: Elsevier.

Crow, D. R. (1979). Principles and Applications of Electrochemistry, 2nd edn. London: Chapman \& Hall.

DAviEs, C. W. (1967). Electrochemistry. London: Newnes.

EDEN, G. \& EDEN, R. (1984). Enumeration of microorganisms by their dynamic ac conductance patterns. IEEE Transactions on Biomedical Engineering BME-31, 193-198.

ERdey-Gruz, T. (1974). Transport Phenomena in Aqueous Solutions. London: Hilger.

FIRSTENBERG-EDEN, R. \& EDEN, G. (1984). Impedance Microbiology. Letchworth, UK: Research Studies Press.

Good, N. E. \& Izawa, S. (1972). Hydrogen ion buffers. Methods in Enzymology 24B, 53-68.

MAHLER, H. R. \& CORDES, E. H. (1971). Biological Chemistry, 2nd edn. New York: Harper \& Row.

MCMURDO, I. H. \& WhYARD, S. (1984). Suitability of rapid microbiological methods for the hygienic management of spray drier plant. Journal of the Society of Dairy Technology 37, 4-9.

OKER-BLOM, M. (1912). Die elektrische Leitfähigkeit im Dienste der Bakteriologie. Centralblatt für Bakteriologie, Abt. I 65, 382-389.

OWENS, J. D., Miskin, D. R., Wacher-Viveros, M. C. \& BENGE, L. C. A. (1985). Sources of conductance changes during bacterial reduction of trimethylamine oxide to trimethylammonium in phosphate buffer. Journal of General Microbiology 131, 13571361.

Parsons, L. B. \& Sturges, W. S. (1926). The possibilities of the conductivity method as applied to studies of bacterial metabolism. Journal of Bacteriology 11, 177-188.

PARSONS, R. (1959). Handbook of Electrochemical Constants. London: Butterworths.

Pethybridge, A. D. (1982). Study of association in unsymmetrical electrolytes by conductance measurements. Zeitschrift für physikalische Chemie, neue Folge 133, 143-158.

Pethybridge, A. D. \& Taba, S. S. (1982). Precise conductimetric studies on aqueous solutions of $2: 2$ electrolytes. Journal of the Chemical Society : Faraday Transactions 1 78, 1331-1344.

Pethybridge, A. D., Ison, R. W. \& Harrigan, W. F. (1983). Dissociation constant of sorbic acid in water and water-glycerol mixtures at $25^{\circ} \mathrm{C}$ from conductance measurements. Journal of Food Technology 18, 389-396.

PIRT, S. J. (1975). Principles of Microbe and Cell Cultivation. Oxford: Blackwell.

Richards, J. C. S., Jason, A. C., Hobbs, G., Gibson, D. M. \& Christie, R. H. (1978). Electronic measurement of bacterial growth. Journal of Physics E: Scientific Instruments 11, 560-568.

Roos, W. \& LUCKNER, M. (1984). Relationship between proton extrusion and fluxes of ammonium ions and organic acids in Penicillium cyclopium. Journal of General Microbiology 130, 1007-1014. 
Stark, J. G. \& Wallace, H. G. (1982). Chemistry Data Book, 2nd edn. London: Murray.

STEWART, G. N. (1899). The changes produced by the growth of bacteria in the molecular concentration and electrical conductivity of culture media. Journal of Experimental Medicine 4, 235-243, plates.

UR, A. \& BRown, D. F. J. (1975). Monitoring of bacterial activity by impedance measurements. In
New Approaches to the Identification of Microorganisms, pp. 61-71. Edited by C. G. Hedén \& T. Illéni. New York: Wiley.

UschINSKI (1903). Ueber die Veränderung einiger physikalisch-chemischer Eigenschaften der Nährmedien unter dem Einfluss des Wachstums diverser Mikroorganismen. Centralblatt für Bakteriologie, Abt. I 33, 88-89. 